\title{
$\frac{51}{7}=19$ \\ DR. 2804
}

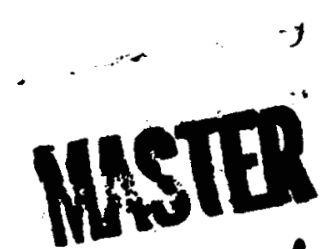

LA-7830-HDR

\section{ENVIRONMENTAL ANALYSIS of the

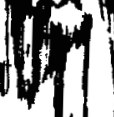
Fenton Hill Hot Dry Rock Geothermal Test Site
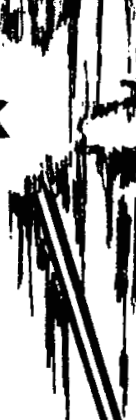

ty

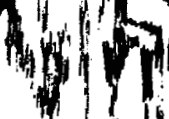

19
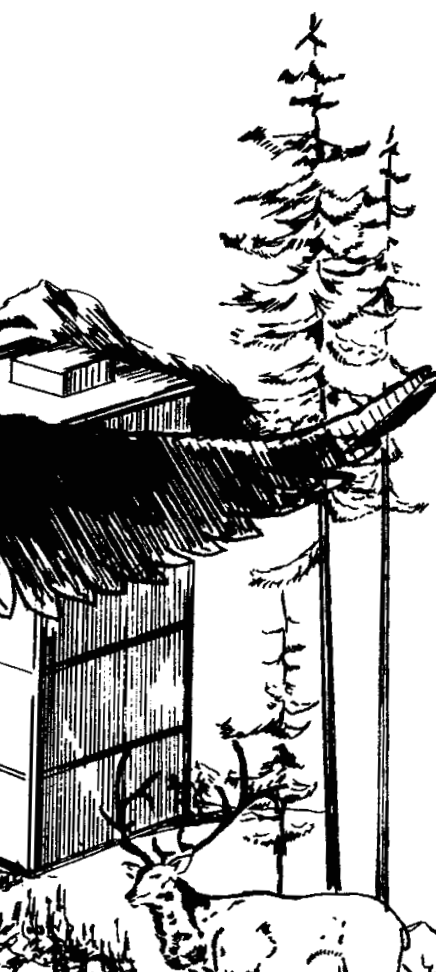


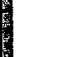

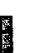

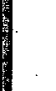


An Affrmative Action/Equal Opportunity Employer

This work was supported by the US Department of Energy, Division of Geothermal Energy.

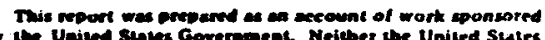

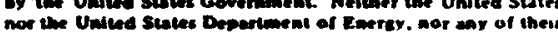

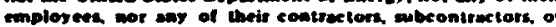

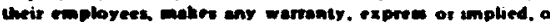

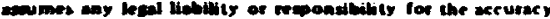

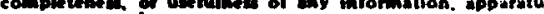

producl, of process dictloued or repremats thut its use would

not infrinee privately owned righte.

UNITED STATES

DEFARTMENT OF ENERGY

CONTRACT w-YQOS-ENG. 


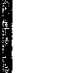


LA-7830-HDR

UC-66e

Issued: May 1979

\title{
ENVIRONMENTAL ANALYSIS of the \\ Fenton Hill Hot Dry Rock Geothermal Test Site
}

\author{
Compiled and Edited by \\ E. L. Kaufman \\ and \\ C. L. B. Siciliano
}

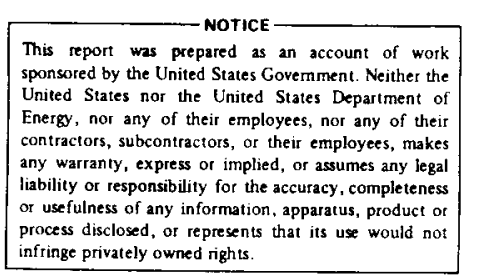




\section{CONTENTS}

ABSTRACT-

I. INTRODUCTION AND PROGRAM HISTORY 1

II. THE HDR SYSTEM AT FENTON HILL-

A. Site Selection and Preparation-_- 5

B. Drilling and Fracturing- 6

C. Surface Facilities-_- 7

III. THE AFFECTED ENVIRONMENT-_- 10

A. Land Status and Uses-_-_ 11

B. Physical Factors- 11

1. Geography and Topography- 11

2. Geology--

3. Seismology-_- 16

4. Hydrology-_- 18

a. Surface Water-_-_- 19

b. Ground Water-1- 23

5. Climatology- 28

6. Aesthetics-_- 30

C. Biological Factors-_- 32

1. Vegetation-1- 32

2. Small Mammals-_-_- 34

3. Elk-_- 35

4. Birds-_- 36

5. Endangered Species-_- 37

D. Social and Economic Factors-_ 38

IV. EFFECTS OF IMPLEMENTATION-_- 40

A. Land Status and Uses-_- 40

B. Physical Factors- 40

1. Geography and Topography-_._. 40

2. Geology-_- 42

3. Seismology-_- 42

a. Activities at the Fenton Hill Site-_ 42

b. Other Activities in the Area and Adjacent Regions--.--- 43

4. Hydrology-C 44

a. Water Requirements-_-_- 44

b. Liquid Effluents-_- 45

5. Climatology-_- 50

6. Aesthetics-_- 50

C. Biological Factors-_- 51

1. Vegetation-- 51

2. Wildlife-- 51

3. Endangered Species-_- 51 
D. Environmental Contaminants-_ 52

1. Air-_-_- 52

2. Water-1-n- 53

3. Water Treatment Plant- 53

4. Noise-_-_- 53

E. Social and Economic Factors- 54

V. SUMMARY- 54

ACKNOWLEDGMENTS-

REFERENCES- 
1. Index Map. 3

2. Schematic of the Fenton Hill Site as it is today... 4

3. Structure of an HDR electricity generating plant.- 7

4. Proposed subsurface array of seismic monitoring stations..._......- 9

5. Schematic of LASL seismic network station with radio telemetry.-.-.- 10

6. Generalized geologic map of the area of investigation. 13

7. Geologic section from the Rio de Las Vacas to San Antonio Creek.---- 13

8. Location of sampling stations. 22

9. Hydrograph to estimate volume of flow near Locations $J$ and $Q$ from US Geological Survey records from gaging station near Location R.-_. 23

10. Chemical analysis comparison of surface water, December 1974.......- 26

11. Chemical analysis comparison of ground water discharges from Cenozoic-Volcanic overlying the Abo Formation.-_- 27

12. Chemical analysis comparison from thermal and mineral springs._._...- 27

13. Schematic casing diagram of GT-2. 27

14. Schematic casing diagram of EE-1. 27

15. Schematic casing diagram of proposed EE-2

16. Location of the weather stations near the site. 29

17. View of Feriton Hill Site from Highway 126. 31

18. Location of vegetation transects. 32

19. Location of small mammal traplines. 34

20. Location of elk pellet groups counting plots... 36

21. Location of bird counting transects. 37

22. Indian reservations in the vicinity of the site. 41 
I. Water Quality Analysis for Horseshoe Spring 19

II. Water Quality Analysis for San Antonio Creek

III. Water Quality Analysis for Holding Ponds

IV. Temperature, Precipitation, and Wind Summaries for 1976

V. Average Percentage of Ground Cover by Community Type

VI. Estimated Nesting Populations at the Well Site and Open Mesa Site During the Summer of 1976

VII. Animal Species Listed as Endangered by the State of New Mexico _...- 39

VIII. Average Chlorides, Fluorides and Total Dissolved Solids (TDS) of Effluents (Ponds) and Water from Sampling Stations, $1978 \ldots$

IX. Chemical Characteristics of Pond Water, Ranges, and Maxima Observed in 1977-78 48

X. Latest Discharge Analysis Results 49 


\title{
ENVIRONMENTAL ANALYSIS \\ OF THE \\ FENTON HILL HOT DRY ROCK \\ GEOTHERMAL TEST SITE
}

Compiled and Edited by

E. L. Kaufman and C. L. B. Siciliano

\begin{abstract}
Techniques for the extraction of geothermal energy from hot dry rock within the earth's crust were tested at the first experimental system at Fenton Hill and proved successful. Because new concepts were being tried and new uses of the natural resources were being made, environmental effects were a major concern. Therefore, at all phases of development and operation, the area was monitored for physical, biological, and social factors. The results were significant because after several extended operations, there were no adverse environmental effects, and no detrimental social impacts were detected. Although these results are specific for Fenton Hill, they are applicable to future systems at other locations.
\end{abstract}

\section{INTRODUCTION AND PROGRAM HISTORY}

The Los Alamos Scientific Laboratory (LASL) administered by the University of California has been investigating the feasibility of extracting heat from the very large geothermal resource contained in the hot dry rock within the earth's crust. The technique requires that a borehole be drilled into low-permeability, hot crystalline rock and that a large, hydraulically fractured region be created near the bottom of this borehole. A second borehole is drilled along a trajectory to intersect the fracture and complete the subterranean portion of the circulation loop. Then pressurized fluid, in this case water, is pumped down one borehole to the "reservoir" where it is heated as it flows over rock in the range of $250^{\circ} \mathrm{C}$. The water, now at temperatures 
in excess of $100^{\circ} \mathrm{C}$, is brought to the surface and directed through heat exchangers before being recycled through the system. The thermal energy that is extracted can be used for generating electricity or directly as heat. This is an efficient system, which has minimal water loss, low noise levels, and few of the other environmental problems associated with hydrothermal systems (such as The Geysers in California). 1-3

Active work on this concept began at LASL in 1970 under sponsorship of the US Atomic Energy Commission (AEC). The Fenton Hill Site, selected in 1973, is located in north-central New Mexico in section 13, T19N, R2E, NMPM, as shown on Fig. 1. Field work was initiated in fiscal year 1974 (FY74), and during the period FY74 through FY76, the two boreholes GT-2 and EE-1 (Geothermal Testhole 2 and Energy Extraction hole 1) were drilled. The necessary surface facilities, such as heat exchangers and water storage, were connected into the system, and energy production tests were conducted. Figure 2 is a schematic of the site as it is today. Because the area chosen for the Hot Dry Rock Geothermal Energy Development Project (HDR Project) is on a part of the Santa Fe National Forest (SFNF), it is under the jurisdiction of the Department of Agriculture, US Forest Service (USFS). A Memorandum of Understanding between the AEC and the Forest Service was written to define the land, the basis of use, and responsibilities of both parties, SFNF (Contract AT 29-1 - 2213, signed November 30, 1973). In addition, the Jemez District Ranger of the Santa Fe National Forest completed an Environmental Analysis Report and determined that initial operations through the drilling phases were acceptable by environmental and public-land-use standards. This report, dated April 3, 1978, states,

"This [Fenton Hill Complex] does not constitute a major federal action. It does not involve an irretrievable commitment of the resource. An Environmental Impact Statement is not needed."

A later Memorandum of Understanding (Contract No. DE-AC32-79AL10001) between the USFS and the Department of Energy (DOE) dated January 3, 1979, provides, in summary, that:

- 1457 hectares (3600 acres) are excluded from known Geothermal Resource Area leasing for the HDR experimental site, but specifically excluding use for commercial electricity generation;

- Various locations, in addition to the site and subject to approval 


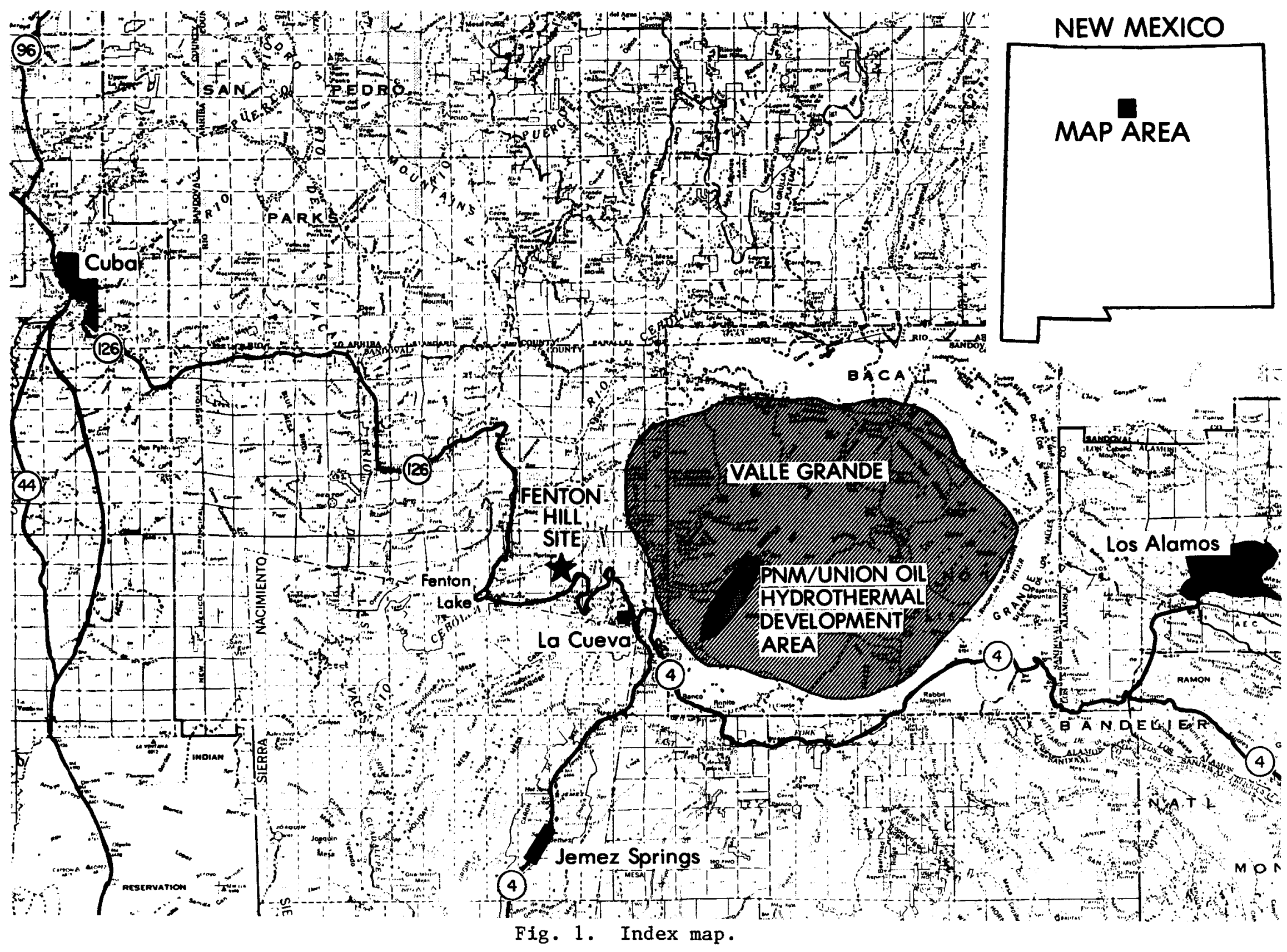


by the District Ranger, may be used for heat flow, geophysical, geological, and environmental monitoring;

- DOE will take all reasonable precautions to minimize damage to the soil, flora, and fauna, that might result from its operations and will comply with the applicable regulations of the Forest Service;

- DOE will submit sixty days in advance for written approval by the Forest Supervisor the development plans, layout plans, plans for construction, reconstruction, or alteration or improvement of facilities to be located on Forest Service land. DOE will prepare for the Forest Supervisor appropriate Environmental Analysis Reports so that the Forest Supervisor may assess project impacts and design mitigating measures. Approved activities will then be coordinated through the appropriate District Ranger;

- DOE will submit in advance for approval by the District Ranger plans and activities of a temporary nature that comply with overall plans and that do not include significant surface disturbance, road building, or drilling in excess of $305 \mathrm{~m}$ (1000 ft) deep. DOE will

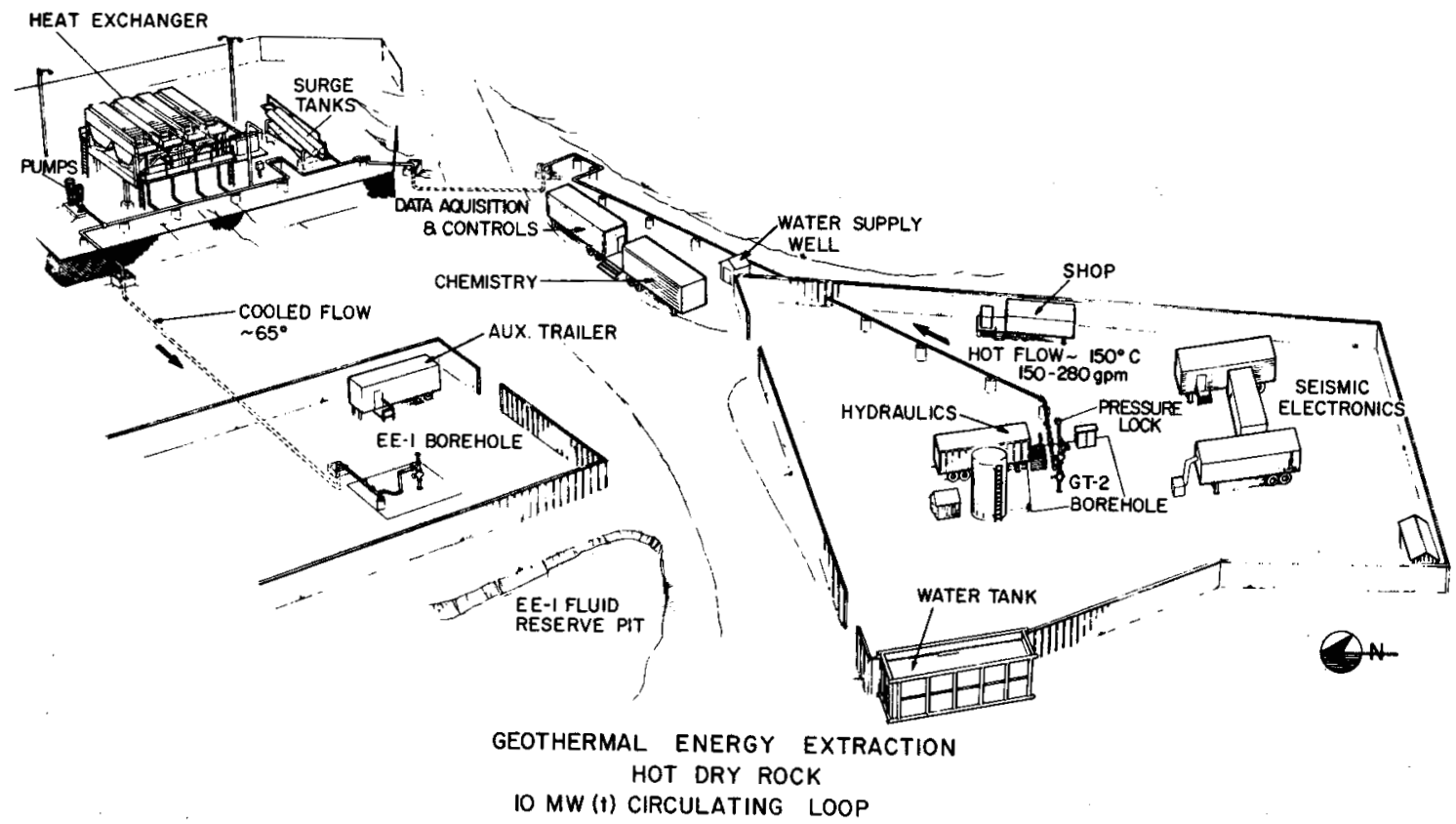

F1g. 2. Schematic of Fenton Hill Site as it is today. 
prepare for the District Ranger appropriate Environmental Analysis Reports so that the District Ranger may assess project impacts and design mitigating measures;

- DOE will provide, for Forest Service review and comment, ecological and environmental study plans and will draft manuscripts related to the surface environment and its renewable resources; and,

- All parties shall comply with applicable federal, state, and local laws and regulations.

\section{THE HDR SYSTEM AT FENTON HILL}

Analysis of the Fenton Hill Site and its operation will provide the initial guidelines for development of future HDR systems at other locations. The present system was designed to determine the flow parameters and to test operation with accelerated thermal drawdown (the rate at which rock temperatures are reduced). The results were as follows.

- Water loss through permeation in the reservoir rock stabilized at $<2 \%$ of the circulation rate.

- The circulating water dissolves some of the soluble constituents of the rock, but the concentration of total dissolved solids stabilized at $2000 \mathrm{ppm}$, which is near drinking water quality.

- There are no gaseous emissions during operation of the circulation loop. However, during some reservoir and equipment testing, water is diverted to storage and then dissolved gases may be released. The composition of the gas was analyzed as $87 \%$ air and $13 \%$ carbon dioxide, with only trace amounts of hydrogen sulfide and ammonia.

- Dissolved radioactive elements were minimal, and these had short half-lives that rendered them undetectable after a few days.

- Noise levels during loop operation approximated those of a typical street corner.

- This does not represent a significant depletion of a natural resource.

\section{A. Site Selection and Preparation}

The effects of injecting fluid into artificially created reservoirs are still being studied. During all phases of development and operation, a very 
sensitive array of selsmometers is used to detect any possible induced microearthquakes. But until it is thoroughly demonstrated that this process will not affect the natural tectonics, sites will not be located in earthquakeprone areas or along major geologic faults.

A small surface area of 5.5 hectares (13.5 acres) was cleared to accommodate the Phase I experimental system. This site Included both boreholes, the heat exchangers, water storage, and all support facilities required for the extraction of $5 \mathrm{MW}$ of thermal energy. To include a demonstration electricity generating plant, the site may have to be expanded somewhat but would require only the clearing and leveling of the specific land to be used. This is insignificant when compared with the amount and use of land required for the strip mining of coal.

HDR facilities can be located within or near cities without concern for possible hazards or contamination because all effects will be restricted to the site. Furthermore, studies are being made of all federal, state, and local laws and regulations that are applicable to the establishment and operation of these systems.

\section{B. Drilling and Fracturing}

During the production of the Phase I reservoir, on-site and regional arrays of selsmometers were used to record any induced microearthquakes. None were detected, and the creation of the next, Phase II, system at the site will be monitored by additional stations. This reservolr will require drilling a new well, deepening one of the existing wells, and creating a second fracture below the first one. The fracture may be several hundred meters long but only a few millimeters wide. This reservoir will be of a commercially feasible size and will demonstrate the production lifetime of such a system.

The diagnostic and fracture-forming operations will be carried out in the new wellbore (EE-2). The fracture will be formed by injecting water down the cased hole at an adequately high pressure to open the cracks in the granitic rock at the bottom of the hole. A similar method produced the existing system, and pumping and fluid-handling equipment will be temporarily located near the EE-2 wellhead to support these operations. The final configuration of the fracture system will depend on the exact nature of the rock formation encountered at the bottom of the hole. The designation of the present land area of $\backsim 1457$ hectares (3600 acres), which is excluded from the known 
Geothermal Resource Area (KGRA) leasing program, will ensure that the entire subsurface reservoir is confined to the excluded land. Then wellbore EE-1 will be redrilled along a trajectory to intersect the fracture system produced near the bottom of EE-2.

After drilling EE-2, a redrilling operation will be carried out on the remalning well GT-2. The wellbore depth will be increased to $s 4 \mathrm{~km}$ (13 000 ft), and a tower will be erected over the wellhead. The redrilled wellbore will be a downhole facility for a Deep-Wellbore Equipment Test Station (DWETS). A service building or trailer and a cable-handling drawworks will be placed near the wellhead.

\section{Surface Facilities}

The support facilities required for operation are minimal. Aside from the trailers for housing equipment and work areas, the main facilities at Fenton HIll are heat exchange modules, 15-m (48-ft) towers over the wellheads, a makeup-water tank, a water storage

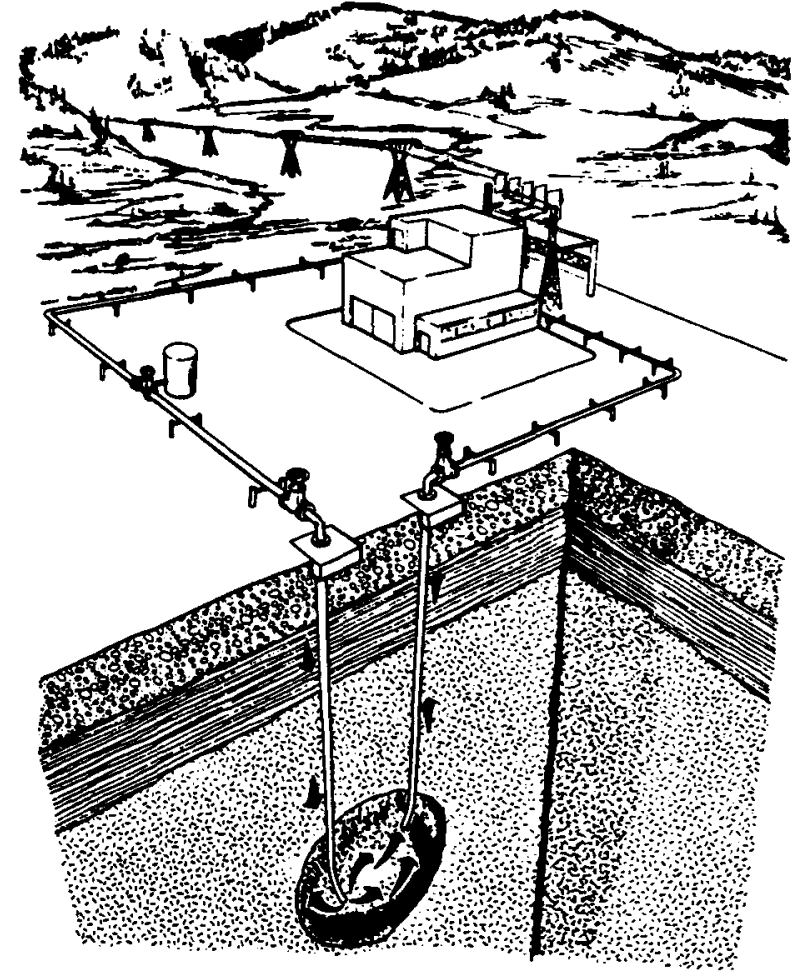

Fig. 3. Structure of an HDR electricity generating plant. pond, and a piping system of the circulation loop. A small, electricity generating plant for demonstration may be included. This portable, 60-kVA unit can be patched into the incoming electric utility lines and, when the energy-extraction loop is operating, can provide up to $12 \%$ of the site demand. Figure 3 shows the structure of a possible HDR plant for commercial production of electricity. By screening with fencing and trees and by selection of appropriate paint colors, an HDR plant would not greatly affect the aesthetics of the area.

A small ( $\sim 9$ by $12 \mathrm{~m}$ or 30 by $40 \mathrm{ft})$ geothermally heated greenhouse might also be installed at Fenton Hill for controlled plant and fish 
physiology experiments (such as effects of geofluid uptake). Heating of this unit would be augmented by a passive solar-energy system and by a back-up fossil-fuel heating system for periods when the loop is not operating.

The larger, Phase II reservoir is expected to require additional water storage, treatment, and production facilities. The alternatives for water storage are covered tanks, excavated holding ponds, and earth fill dams. The anticipated storage capacity will range from 22700 to $45000 \mathrm{~m}^{3}$ (5 to $10 \mathrm{Mgal})$. To store $\sqrt{34} 000 \mathrm{~m}^{3}(7.5 \mathrm{Mgal})$, a pond with dimensions of $\sqrt{91} \mathrm{~m}$ $(300 \mathrm{ft})$ in diameter and $\sqrt{3 \mathrm{~m}}(10 \mathrm{ft}$ ) deep would be required. The maximum water-surface area would be $\Omega .8$ hectares (2 acres). A single tank of $26000 \mathrm{~m}^{3}(5.7 \mathrm{Mgal})$ capacity would be $\sqrt{ } 61 \mathrm{~m}(200 \mathrm{ft})$ in diameter and $9 \mathrm{~m}$ (30 ft) high.

A water treatment facility, if needed, would consist of a number of modular treatment units housed in a suitable weather-protective enclosure. This facility will be used for treatment and conditioning of water circulated in the heat-extraction loop, including possible removal of dissolved minerals, and treatment of water for release from the site to meet Environmental Protection Agency (EPA) effluent limits, pursuant to a National Pollutant Discharge Elimination System (NPDES) permit.

This larger fracture system may require a new water-supply well that would be drilled on the site and produce from a depth interval of 305 to $732 \mathrm{~m}$ (1000 to $2400 \mathrm{ft}$ ). The well drilling and operation will be pursuant to a New Mexico State Engineer's authorization and will comply with USFS regulations.

Certain experimental observations will be made using facilities to be located in the Santa Fe National Forest outside the test site. An existing array of nine seismic monitoring stations in the area surrounding the geothermal site maintain present surveillance. Seven of these are surface stations lying within an $5750-\mathrm{m}$ radius of the site, and the other two are in Holes $A$ and D shown on Fig. 4. Also shown on Fig. 4 are six proposed sites, SI through S4, GT-1, and Hole B. Of these GT-1 and Hole B were drilled before development of the Fenton Hill Complex. SI through S4 are intended to be augered holes $15 \mathrm{~cm}$ ( $6 \mathrm{in.}$ ) in diameter and $30 \mathrm{~m}$ (100 ft) deep. The additional sites will have radio-frequency ( $r f$ ) telemetry for wireless transmission of seismic signals to recording facilities at the site. These seismic stations will require a very small surface disturbance, limited to only that area 
necessary for burying the 30- to 55-gal drums containing the electronic equipment and the area immediately above ground for the solar panels and transmitting antennas as illustrated in Fig. 5.

Another installation will be constructed on Lake Fork Mesa to measure earth strain with equipment of special sensitivity and will be located $1.6 \mathrm{~km}$ (1 $\mathrm{mi}) \mathrm{SW}$ of the geothermal site. The facility will consist of a $10-\mathrm{m}-1$ ong, 0.5-m-deep, and 0.6-m-wide trench with 180-mm-diam, 3-m-deep holes on both ends. Steel pipes 4.5-in. in diameter will be cemented into each hole. The trench will be filled with insulation, cans of water, and covered with a

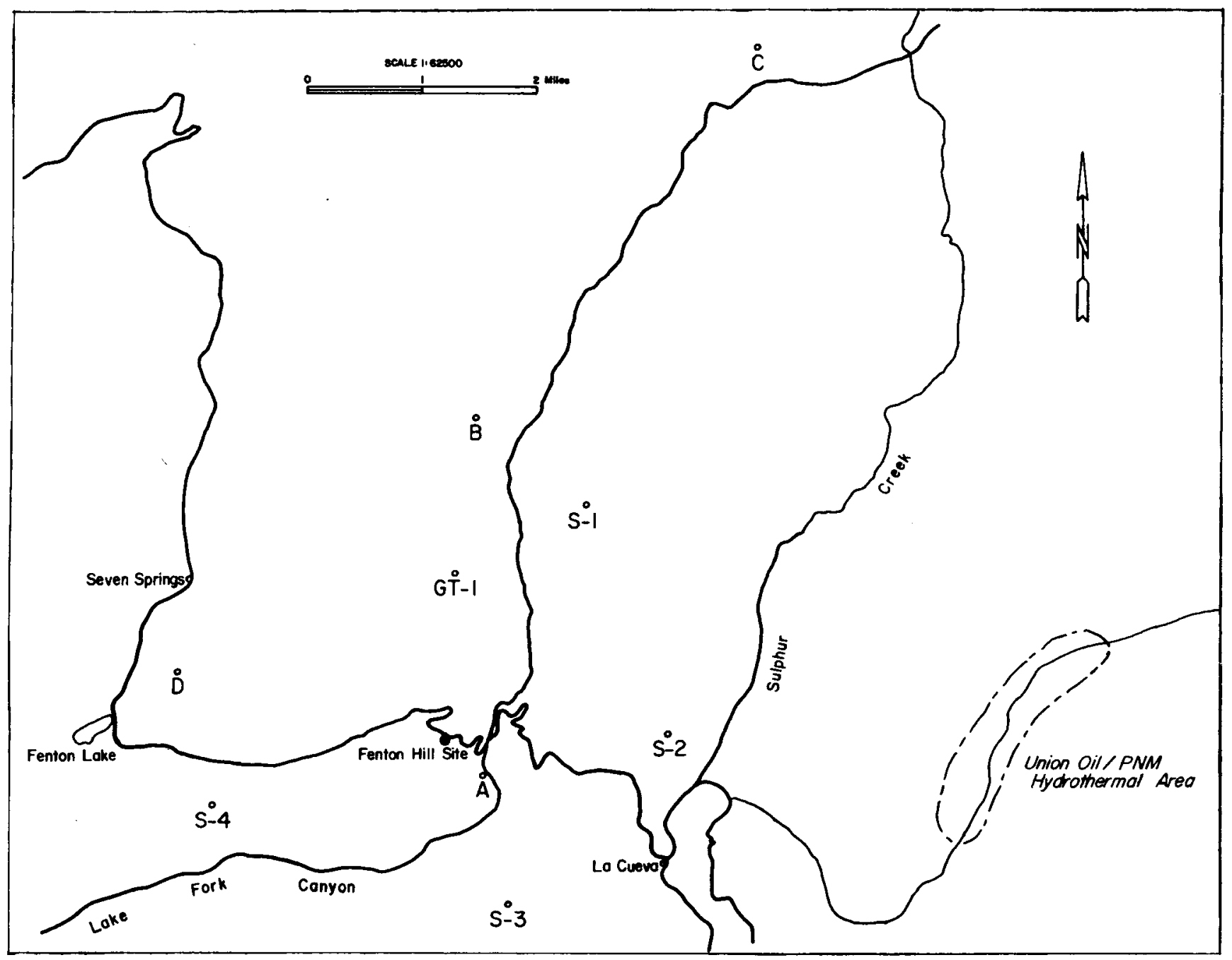

Fig. 4. Proposed subsurface array of seismic monitoring stations. 
tarpaulin. At the end of the trench where the equipment is located a portable shed will be erected.

Approval from the USFS will be obtained before fielding any temporary equipment in the area surrounding the geothermal site in accordance with the stipulations of the latest Memorandum of Understanding.

\section{THE AFFECTED ENVIRONMENT}

Much information on the existing environment, including documentation of effects resulting from the present facilities, has been gathered by LASL through special studies relating to the HDR Project. These include geologic and geophysical investigations, regional hydrology and water quality studies started in 1971, specially funded environmental studies started in 1975, and monitoring conducted as part of LASL's routine environmental surveillance. Reports from these studies are available and are listed in the references.

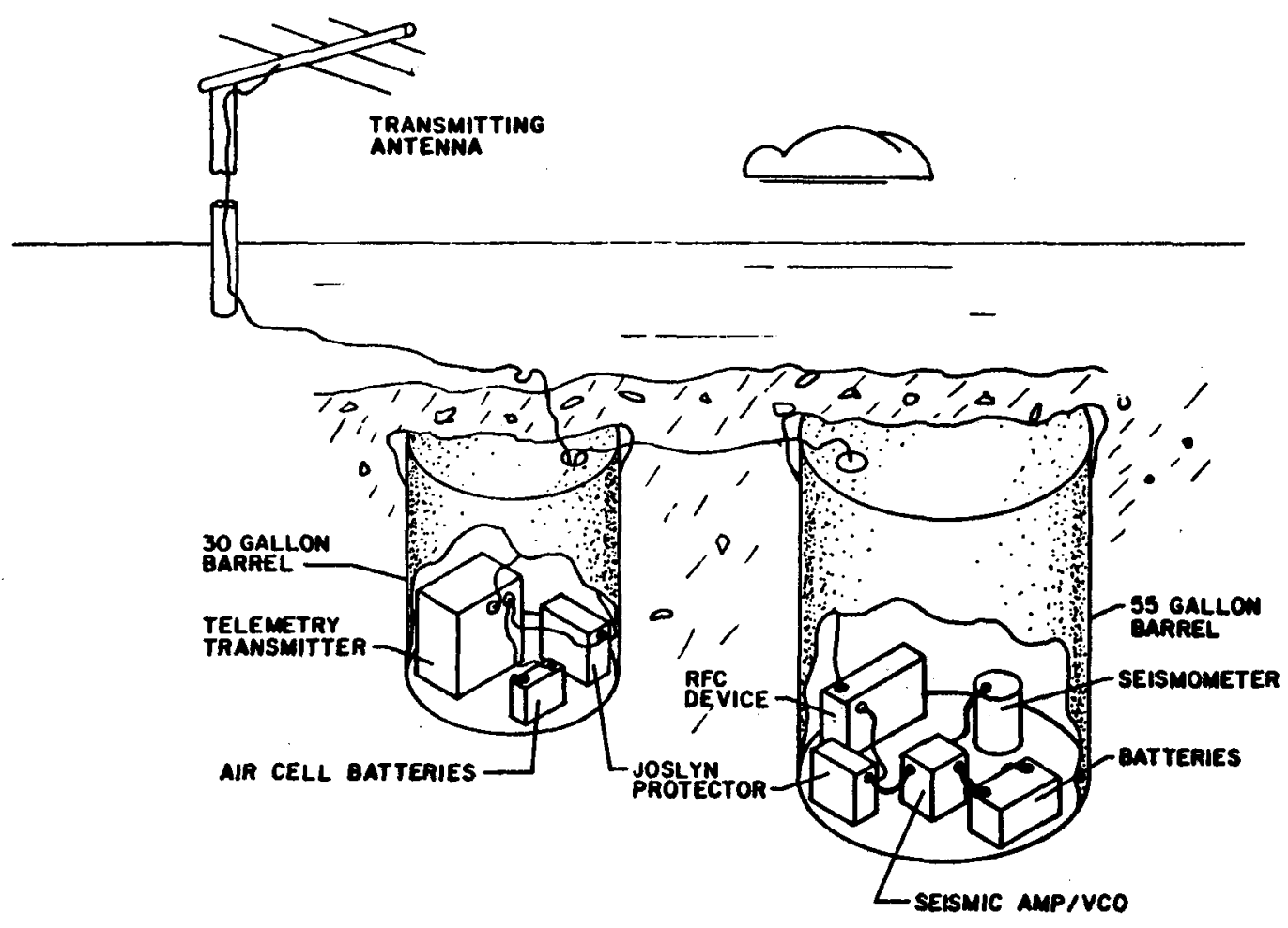

Fig. 5. Schematic of LASL seismic network station with radio telemetry. The solar panels are not shown. 


\section{A. Land Status and Uses}

Based upon an administrative charter, this area is dedicated to the preservation of the natural vegetation, wildlife, and scenic beauty as a segment of the forested high-mesa country of the American Southwest. 4 Multiple-use policies in management of public lands have led to the establishment of a USFS fire control helipad on this plateau, planting of tree seedlings, cattle grazing, fuel wood gathering, hunting, picnicking, etc., and finally to the development of a geothermal test facility. The small surface area 5.5 hectares (13.5 acres) containing the facility will be of limited access, but the rest of the plateau will remain under the multiple-use concept.

Because the Valles Caldera is the central feature of the Jemez Mountains and is one of the world's largest calderas, it is deemed worthy of preservation and has been declared a National Natural Landmark. The nearest boundary of the designated area is $5.5 \mathrm{~km}$ (3.5 miles) away from Fenton Hill. Therefore, geothermal developments at Fenton Hill will not affect the integrity of the landmark area.

The subsurface area, $\Omega 1457$ hectares ( 3600 acres), that will contain the geothermal reservoirs is within the western portion of the Valles Caldera KGRA and is excluded from further leasing.

\section{B. Physical Factors}

1. Geography and Topography. The LASL HDR facility is located on the Jemez Plateau $\backsim 35 \mathrm{~km}(22 \mathrm{mi})$ west of Los Alamos, in north-central New Mex1co. ${ }^{3}$ The Jemez Plateau is a part of the western arm of the Rocky Mountains that extends into northern New Mexico from southern Colorado. The surface of the plateau is formed by volcanic ash extruded during the volcanic activity that produced the Valles Caldera $\sim 1.1$ Myr ago. 5

The Valles Caldera is surrounded by mountains formed during this same period of active volcanism. The volcanic ash forms an apron around the caldera that laps onto the flanks of these mountains, and the Jemez Plateau is the western part of this apron. The north-south trending Nacimiento Mountains form the western boundary of the area of investigation.

The altitudes of mountains bounding the Jemez Plateau on the east and west range from about $3048 \mathrm{~m}(10000 \mathrm{ft})$ at the westernmost dome in the 
caldera (San Antonio Mountain) to a little over $2743 \mathrm{~m}$ (9000 ft) along the crest of the Nacimiento Mountains. The major drainage in the area is the Rio de Las Vacas and Jemez Creek, with its tributary, San Antonio Creek. The Fenton Hill Site is on the plateau between the Rio de Las Vacas and San Antonio Creek. A high ridge along the western part of the plateau is parallel to San Antonio Creek. Otherwise the surface of the plateau slopes gently downward to the west and southwest. The altitude of the area ranges from 2440 to $2740 \mathrm{~m}$ ( 8000 to $9000 \mathrm{ft}$ ) along the crest of the ridge to about 2130 to $2440 \mathrm{~m} \mathrm{(7000} \mathrm{to} 8000 \mathrm{ft}$ ) where the plateau terminates in steep slopes or cliffs above the Rio de Las Vacas. The plateau surface is cut into a number of mesas by southwest trending streams that are tributary to the Rio de Las Vacas, the largest of which is the Rio Cebolla. West of the Rio de Las Vacas, the eastern flank of the Nacimientos rises gently to the crest, then the slope breaks steeply westward into the San Juan Basin.

2. Geology. ${ }^{6,7}$ The site area is a part of the southern extension of the Rocky Mountains and is bounded on the east by the Rio Grande Depression and on the west by the San Juan Basin. Precambrian, Pennsylvanian, Permian, Mesozoic, and Cenozoic rocks outcrop in the area as shown on Fig. 6.

Precambrian rocks of granite and gneiss outcrop along the flanks and crest of the Nacimiento Mountains. These are overlain by Pennsylvanian and Permian limestones, sandstones, and shales. Mesozoic sediments outcrop in the northwestern part of the area and on the western slopes of the Nacimiento Mountains, but because they do not extend beneath the Jemez Plateau they are not further considered. The Cenozoic volcanic rocks form the upper surface of the Jemez Plateau, overlying the Permian, Pennsylvanian, and Precambrian rocks.

The Precambrian rocks are particularly important to the present geothermal energy research because they will contain the pressurized-water circulation system to be created. Granite is the most abundant type of Precambrian rock. The granite is coarse-grained with large insets of microcline. Microcline is the dominant feldspar, although albite-oligoclase is usually present in smaller amounts. Quartz is abundant, with biotite a common mafic mineral.

Quartz-feldspar gneiss is common. The feldspar consists mainly of microcline. However, oligoclase-andesine is also abundant, although it is finer grained and more uniformly spread throughout the rocks. The quartz shows moderate straining. Accessory minerals are hornblende, biotite, epidote, 


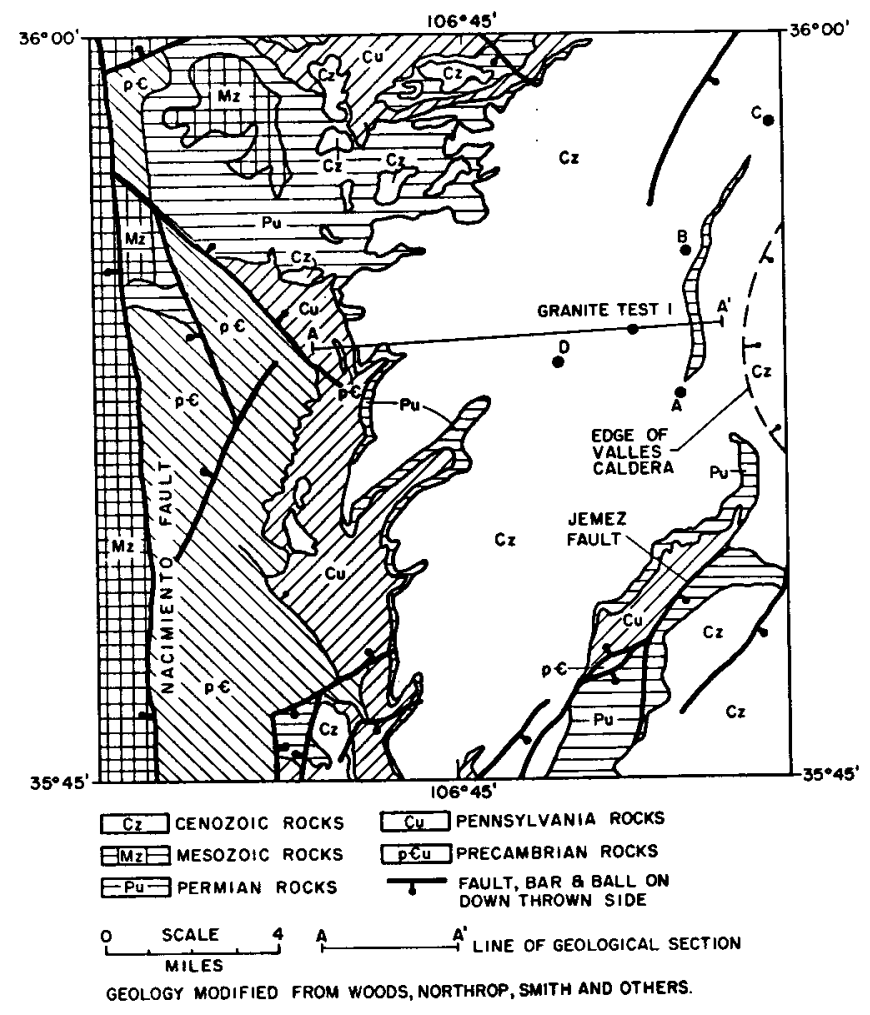

Fig. 6. Generalized geologic map of the area of investigation. (See Refs. 8 and 9.)

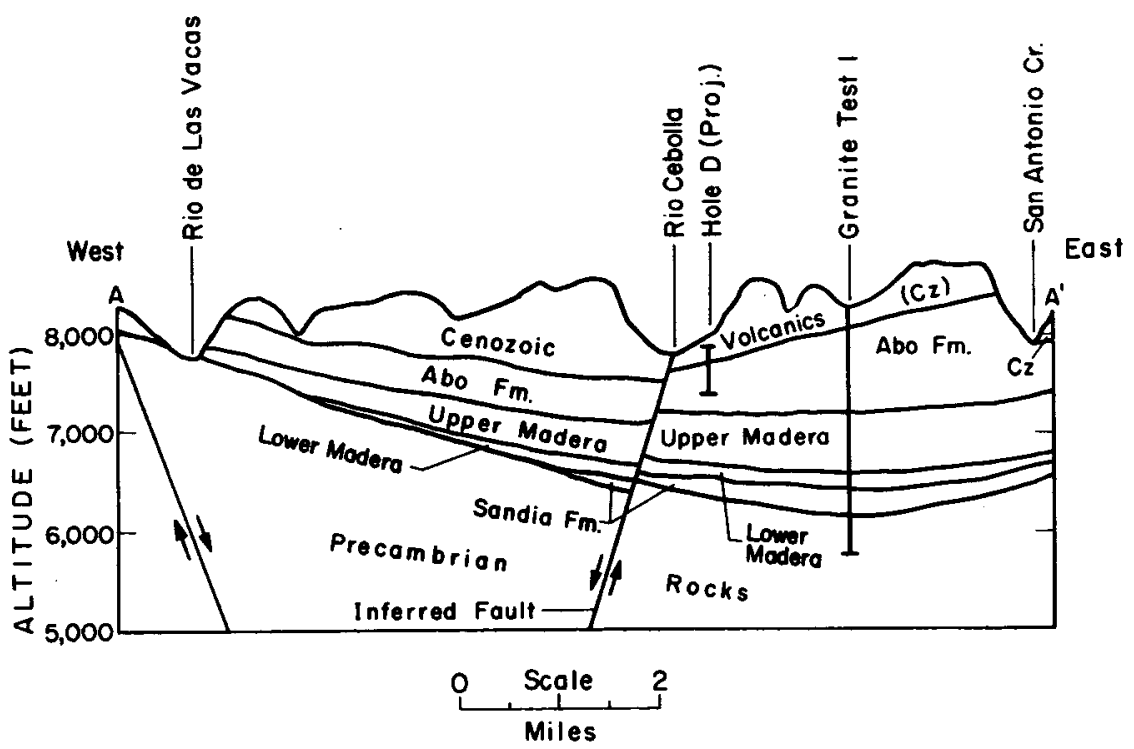

Fig. 7. Geologic section from the Rio de Las Vacas to San Antonio Creek. 
with some sphene, apatite, zircon, and magnetite. GT-1 penetrated augengneiss in which the augen ("eyes") are microcline. The gneiss is lenticular, with planes of foliation. The foliation has a general, characteristic northeast trend, that has also been observed to the southeast in the Sandia, Manzanito, and Manzano Mountains--as if deformation and metamorphism had taken place in a single major event with forces acting at right angles to the foliation.

GT-1 penetrated a dark gray amphibolite that is primarily amphibole and plagioclase. A few small outcrops of Precambrian occur along the Rio de Las Vacas. There are no apparent outcrops of pegmatites or greenstone schists, although there are a few outcrops of mica schist into which the granites have intruded. The color of the granites ranges from brownish-gray to red, whereas the predominant color of the gneiss ranges from pinkish-gray to red. The granites weather to spheroidal boulders and hummocks. The gneiss weathers to rounded knolls and undulating uplands.

The Pennsylvanian rocks are predominantly massive limestones, shales, and arkose. In the area of investigation these rocks compose the Magdalena Group that includes the lower Sandia formation and overlying Madera limestone. Although these strata are combined on the map of Fig. 6, the cross section of the experimental site in Fig. 7 shows individual units within the two formations. The Sandia formation is divided into a lower limestone member and an upper clastic member. The lower member is a dark gray, siliceous limestone, whereas the overlying member consists of dark brown to brownish-green sandstone and arenaceous shale and limestone. The lower limestone member is discontinuous. The upper clastic member rests on the Precambrian rocks in some areas. Both members were present in GT-1.

The Madera limestone is composed of a lower, gray limestone member and an upper arkosic limestone member. The lower gray limestone consists of a dark gray limestone interbedded with gray shale and a few sandstone beds. The upper arkosic limestone member is of limestone and arkosic limestone, alternating with gray and red arkosic shale.

The thickness of the Pennsylvanian rocks of the Magdalena Group varies, and in some places they are not present--either because they were removed by erosion before deposition of the overlying Permian rocks or because they were not deposited. 
The Permian rocks were deposited on an old flood plain that may have been flooded periodically by marine waters, although the irregular bedding in the sandstones suggests a fluvial mode of deposition for most of the rocks, in a continental environment.

In the area of investigation the Permian rocks are of the Abo formation. The formation consists of arkosic siltstone, sandstone, and shale. The sandstone is fine-grained with occasional lenses of pebbly conglomerate. Lenses of clay also occur, as well as some minor, thin lenses of arkosic limestone. The formation is made up of alternating layers of shale, siltstone, sandstone, and clay, with the shales making up the larger part of the section. Quartz grains are numerous in coarser-bedded material; however, some feldspar is also present, as well as small particles of igneous rocks. The Abo in the lower part of the section may contain some reworked material from the Magdalena Group. The color of the formation is predominantly various shades of red, from light to very dark. The upper surface of the Abo was heavily eroded prior to the deposition of the Cenozoic volcanics. Thus the thickness of the Abo varies because of this irregular surface. Testholes A, B, C, and D, shown on Fig. 6, did not penetrate the complete section of the Abo but are completed $101,64,52$, and $115 \mathrm{~m}$, respectively, into the upper part of the formation.

The Cenozoic rocks are made up of volcanics and clastics. ${ }^{8,9}$ The older Cenozoic rocks--the Abiquiu Tuff and the Tschicoma formation--are exposed in the west wall of the canyon cut by San Antonio Creek north of La Cueva, whereas the younger rocks--the Bandelier Tuff--form the upper part and surface of the Jemez Plateau. The Abiquiu Tuff lies in the topographically low areas in the eroded surface of the Abo formation. It is composed mainly of white to light gray tuffaceous sandstone and conglomerate that includes a basal gravel member that includes pebbles and sand derived from the Precambrian crystalline rocks. Testhole A, Testhole C, and GT-1 penetrated the Abiquiu Tuff at 38, 103 , and $30 \mathrm{~m}$, respectively.

The Tschicoma formation overlies the Abo formation and a part of the Abiquiu Tuff along the west wall of the canyon cut by San Antonio Creek. The formation is a thin pyroclastic flow of dark gray latite that, in places, contains some thin lenses of light gray clay. The formation contains phenocrysts of plagioclase and some smaller crystals of quartz, biotite, hornblende, and augite in a fine-grained gray matrix. Testhole $\mathrm{B}$ penetrated about $18 \mathrm{~m}$ of the Tschicoma above the Abo formation. 
The Bandelier Tuff forms the upper part and the surface of the Jemez Plateau overlying the older volcanic rocks of the Tschicoma formation--Abiquiu Tuff and, in places, the sediments of the Abo formation. The Bandelier Tuff ranges from a nonwelded to a welded rhyolite tuff, with colors from light gray to dark gray. The tuff is made up of crystals and crystal fragments of quartz and sanidine, glass shards, and some mafic minerals; as. well as rock fragments, pumice, latite, and rhyolite in a fine-grained ash matrix. The Bandelier Tuff thins to the west and southwest away from the source area, the Valles Caldera. Testholes A, B, $C$, and D, and GT-1 penetrated thicknesses ranging from 9 to $115 \mathrm{~m}$ of the Bandelier Tuff.

3. Seismology. ${ }^{3}$ Historically, New Mexico is an area of low-to-moderate seismic risk. Records of shocks felt by people or causing structural damage date back to the mid-1800s. These records, coupled with instrumental measurements, show the greatest earthquake activity region centered along the Rio Grande Valley between the cities of Socorro and Santa Fe in the central part of the state. 10

Although historical records show the Jemez Plateau to be quiet, a survey to locate fault and seismic events was deemed necessary. ${ }^{10,11}$ These data were used to document the absence of large seismic events within the region and to check the site specifically for induced seismicity from circulating water through deep earth structures. A survey was done in 1971 to determine the proximity and probable activity of faults near the site. ${ }^{12}$ This survey shows that the Jemez fault zone is the nearest major fault system to the site. Two northeast-trending faults within this zone, the Virgin Canyon fault and the Jemez Springs fault, pass within 4 and $7 \mathrm{~km}$, respectively, from the site. Field checks of both faults indicate their displacement (rate of movement per year) is far below that of major active faults in the western United States. It is highly improbable that these faults would be activated by experimentation at the LASL HDR Site because of their distance from the site, the fact that they trend away from the site, and their relatively low displacements.

Two sets of seismic nets (close-in and on-site) were established to measure seismic activity in the vicinity of the site and to supplement measurements taken from three stations (Barley Canyon, Lake Fork Canyon, and La Cueva) on an existing regional net. The regional net, established to measure seismic events important to LASL, is indirectly linked to the Fenton Hill 
Project. This net is composed of 12 high-gain, continuously telemetered stations located $5150 \mathrm{~km}$ from Los Alamos. The regional net was started in 1972 with establishment of the first station at LASL. By 1973, enough stations were functional to locate epicenters of microearthquakes Richter's magnitude thresholds $\left(M_{L}\right)>0.5$ up to $100 \mathrm{~km}$ from Los Alamos. 13

The La Cueva station, located $\sim 450 \mathrm{~m}$ north of the site, contains a three-axis system of seismometers. The Barley Canyon and Lake Fork Canyon systems are special borehole (125-m-deep) stations that were established in 1975 to augment the detection and location capabilities of $M_{L}>0$ seismic events within $5 \mathrm{~km}$ of the site.

The close-in and on-site seismic nets were established during 1975 and 1976 to detect signals from the $\$ 2900 \mathrm{~m}$-deep hydraulic fracturing experiments. The close-in seismic net consists of nine surface stations located $\Omega 1500$ to $2000 \mathrm{~m}$ from the site, and the rest are $9750 \mathrm{~m}$ from the site in a circular configuration. Signals from these stations are transmitted by cable to a recording trailer at the site.

Microseismic events recorded by the regional network of seismic stations in northern New Mexico show that no events greater than the threshold value $M_{L}=0.5$ have occurred at the site since 1973. Microseismic activity recorded near the facility is discussed below.

The first event recorded with an epicenter near the facility occurred in the early morning of May 28, 1975. This was a single shock $\left(M_{L}=0.7\right)$ $\Omega 17 \mathrm{~km}$ southeast of the site. Because this was a singular event, its significance remains unclear.

A larger event was recorded later that year, on September 29. This activity was preceded by two shocks, recorded on the September 25 and 27, and was followed by a series of aftershocks in a classical earthquake fashion. The main shock $\left(M_{L}=3.2\right)$ took place $\$ 22 \mathrm{~km}$ northwest of the site and was of such magnitude that sensitive instruments throughout the state measured it. This event, one of several associated with the Nacimiento Mountains fault zone, demonstrates that this fault system is still active. As of January 1977, no other significant shocks have been recorded near the site by the seismic network.

During 1975 and 1976 attempts were made to measure the noise generated by hydrofracturing experiments at depths of $\Omega 2900 \mathrm{~m}$ within boreholes penetrating the Precambrian granitic rocks. Because surface stations of both the close-in 
and on-site seismic nets were unable to separate these events from background noise, special downhole geophones were installed to monitor these activities. To date, the seismic nets have not recorded a measureable surface seismic event caused by operations at the Fenton Hill project.

4. Hydrology. ${ }^{3}$ The geothermal site is situated near major drainages that support natural fisheries and contribute water supplies to several small towns and villages. Any effects on these surface waters must be documented and potential relationship to the project's operation examined. In addition to the surface water problem, the potential exists for pollution of aquifers because of the nature of the experiments. Therefore, base line data were established to document the water quality of the region before and after establishing the HDR Facility. 14

In 1973, a preliminary study was made of both surface and ground waters in drainages surrounding the site. This study relied on both a literature search for information before 1971 and summaries of field data collected between 1971 and 1973. In 1974, additional data were taken from springs in the Lake Fork Canyon and on the Jemez River and from several surface locations adjacent to the site. In 1975 and 1976, 9 surface water stations and 14 ground water stations were monitored in the various drainages. These data were augmented by samples taken from storage ponds and borehole fluid at the site. 15,16

Chemical analyses were made to determine levels of silica, calcium, magnesium, sodium, carbonate, bicarbonate, sulfate, chloride, fluoride, nitrate, and total hardness. Measurements were also made for total dissolved solids, conductance, and acidity. All analyses were conducted according to the procedures outlined in Ref. 16.

Results of the chemical analyses for water quality are summarized in Tables I-III. 14,17 These data represent one ground water station, one surface water station, and the two holding ponds at the HDR Site. No significant differences were observed in either the surface or ground water samples. However, some fluctuations did occur seasonally within years and seasonally between years. These data show that there is little difference between the ground water (potable supply) and surface water adjacent to the site. The ground water is slightly higher in silica $\left(\mathrm{SiO}_{2}\right)$, whereas the surface water 
is higher in calcium ( $\mathrm{Ca}$ ). This difference is expected because of the soil and rock material in contact with these waters.

The water from the holding ponds at the site has been used for various experiments. These waters have become contaminated by various elements and compounds that have changed their chemical composition (see Table III). Nevertheless, these waters will be treated by various processes before release to the local environs pursuant to a National Pollutant Discharge Elimination System (NPDES) permit, presently in review by EPA.

a. Surface Water. ${ }^{7,14}$ Surface water in the tributaries (Redondo, Sulphur, and San Antonio Creeks) to the Jemez River is analyzed continually to determine if any effect on the water quality results from geothermal operations

TABLE I

WATER QUALITY ANALYSIS FOR HORSESHOE SPRINGa

\begin{tabular}{|c|c|c|c|c|}
\hline & 1974 & 1975 & 1976 & Mean \\
\hline Silica ${ }^{\mathrm{D}}$ & 78.5 & 83.7 & 73.3 & 78.5 \\
\hline Calcium & 11.0 & 10.7 & 12.3 & 11.3 \\
\hline Magnesium & 3.5 & 2.7 & 3.7 & 3.3 \\
\hline Sodium & 17.2 & 15.0 & 16.3 & 16.2 \\
\hline Carbonate & 0 & 0 & 0 & 0 \\
\hline Bicarbonate & 74.0 & 62.7 & 65.7 & 67.5 \\
\hline Sulfate & 6.0 & 3.8 & 3.2 & 4.3 \\
\hline Chloride & 10.0 & 4.7 & 3 & 5.9 \\
\hline Fluoride & 0.3 & 0.2 & 0.3 & 0.3 \\
\hline Nitrate & 0.2 & 0.2 & 0.2 & 0.2 \\
\hline Total dissolved solids & 181.0 & 154.7 & 171.3 & 169.0 \\
\hline Total hardness & 42.0 & 38.7 & 46.0 & 42.2 \\
\hline $\begin{array}{l}\text { Specific conductance } \\
(\mathrm{mS} / \mathrm{m})\end{array}$ & 15.5 & 13.8 & 14.7 & 14.7 \\
\hline pH & 7.5 & 7.2 & 7.8 & 7.5 \\
\hline
\end{tabular}

"Ground water station near the HDR site.

"Chemical analyses in milligrams/liter. 
TABLE II

WATER QUALITY ANALYSIS FOR SAN ANTONIO CREEK ${ }^{a}$

\begin{tabular}{lrrrrr} 
& 1974 & 1975 & & 1976 & Mean \\
\cline { 2 - 3 } \cline { 5 - 6 } & & & & \\
Silicab & 47.8 & 51.0 & 51.3 & 50.0 \\
Calcium & 16.2 & 16.7 & 15.0 & 16.0 \\
Magnesium & 2.6 & 3.0 & 5.6 & 3.7 \\
Sodium & 14.8 & 12.7 & 13.3 & 13.6 \\
Carbonate & 0 & 0 & 0 & 0 \\
Bicarbonate & 69.6 & 70.0 & 62.7 & 67.4 \\
Sulfate & 9.4 & 6.4 & 6.8 & 7.5 \\
Chloride & 4.8 & 2.3 & 3.0 & 3.4 \\
Fluoride & 1.1 & 0.9 & 1.2 & 1.1 \\
Nitrate & 0.2 & 0.1 & 0.1 & 0.1 \\
Total dissolved solids & 190.0 & 159.3 & 168.3 & 172.5 \\
Total hardness & 50.4 & 54.7 & 60.7 & 55.3 \\
Specific conductance & 15.2 & 17.0 & 16.2 & 16.1 \\
$\quad$ (mS/m) & & & & \\
pH & 7.7 & 8.0 & 7.5 & 7.7 \\
\end{tabular}

'Surface water station near the HDR site.

'Chemical analyses in milligrams/liter.

TABLE III

WATER QUALITY ANALYSIS FOR HOLDING PONDS ${ }^{a}$

\begin{tabular}{|c|c|c|c|c|}
\hline & 1974 & 1975 & 1976 & Mean \\
\hline Silica ${ }^{b}$ & 61.4 & 49.3 & 119.2 & 76.6 \\
\hline Calcium & 56.2 & 42.2 & 24.2 & 40.9 \\
\hline Magnesium & 5.9 & 3.2 & 5.8 & 5.0 \\
\hline Sodium & 868.1 & 120.0 & 358.3 & 448.8 \\
\hline Carbonate & 213.5 & 77.5 & 55.7 & 115.6 \\
\hline Bicarbonate & 1006.9 & 244.5 & 386.3 & 545.9 \\
\hline Sulfate & 492.4 & 173.7 & 169.8 & 275.3 \\
\hline Chloride & 831.5 & 145.0 & 271.7 & 416.1 \\
\hline Fluoride & 3.1 & 1.1 & 11.3 & 5.2 \\
\hline Nitrate & 26.3 & 0.8 & 1.6 & 9.6 \\
\hline Total dissolved solids & 3840.2 & 1210.5 & 1345.7 & 2132.1 \\
\hline Total hardness & 163.5 & 119.0 & 84.7 & 122.4 \\
\hline $\begin{array}{l}\text { Specific conductance } \\
(\mathrm{mS} / \mathrm{m})\end{array}$ & 482.3 & 171.8 & 215.7 & 289.9 \\
\hline $\mathrm{pH}$ & 9.3 & 8.4 & 8.1 & 8.6 \\
\hline
\end{tabular}

-Water holding ponds at the HDR site.

'Chemical analyses in milligrams/liter. 
in the Valles Caldera. The Rio Cebolla below Lake Fork Canyon and the Rio Guadalupe above the Jemez River are monitored because of surface run off from the site and contributions of ground water from volcanic rocks underlying the site. The base of streams in the Jemez River drainage is from shallow ground water systems in the Valles Caldera and thermal or mineral springs. The base flow in the Rio Cebolla is mainly from springs discharging from volcanic rocks that form the western flank of the Valles Caldera. The volcanics are underlain by a thick section of sediment that forms a perching layer for water in the volcanics. Each base flow source has a chemical characteristic that may be modified by snowmelt or rainfall run off. Thus, the chemical quality of the surface water can vary widely with the changes in discharge because of precipitation in the drainage area. The discharge of mineral springs into a reach of the stream has a significant effect on water quality.

There are three surface water gaging stations operated by the US Geological Survey (USGS) on the Jemez River and Rio Guadalupe. The operation of stations near Location $J$ and $Q$, shown on Fig. 8, was funded by LASL for the years 1973-1974. The station at Location $J$ is on the Jemez River below the confluence of the East Fork of the Jemez and San Antonio Creek. The drainage area above the station is $448 \mathrm{~km}^{2}$. Discharge at the station includes the run off from the Valles Caldera, as well as adjacent areas. The station at Location $Q$ is on the Rio Guadalupe above the confluence with the Jemez River. The drainage area above the station is $609 \mathrm{~km}^{2}$. Discharge at the station includes drainage from the western rim of the Caldera and the flanks of the mountains to the west. Canyons with intermittent streams north and south of the Fenton Hill Site drain into the Rio Guadalupe. The station at Location $R$ is on the Jemez River below the confluence of the Rio Guadalupe as shown on Fig. 8. The drainage area above the station is $1220 \mathrm{~km}^{2}$. Discharge at the station includes run off passing through the stations at Location $J$ and $Q$ as well as some: stream discharge.

Stream flow characteristics at the three stations are well defined, with

over 16 years of continuous records. The annual volumes of water at the stations at Locations $J$ and $Q$ can be estimated from records of the station near Location R. A hydrograph was prepared to estimate the annual volumes of water passing stations at Locations $J$ and $Q$ using the station at Location $R$ for control as shown on Fig. 9. The latter is equipped with a digital, as well as 


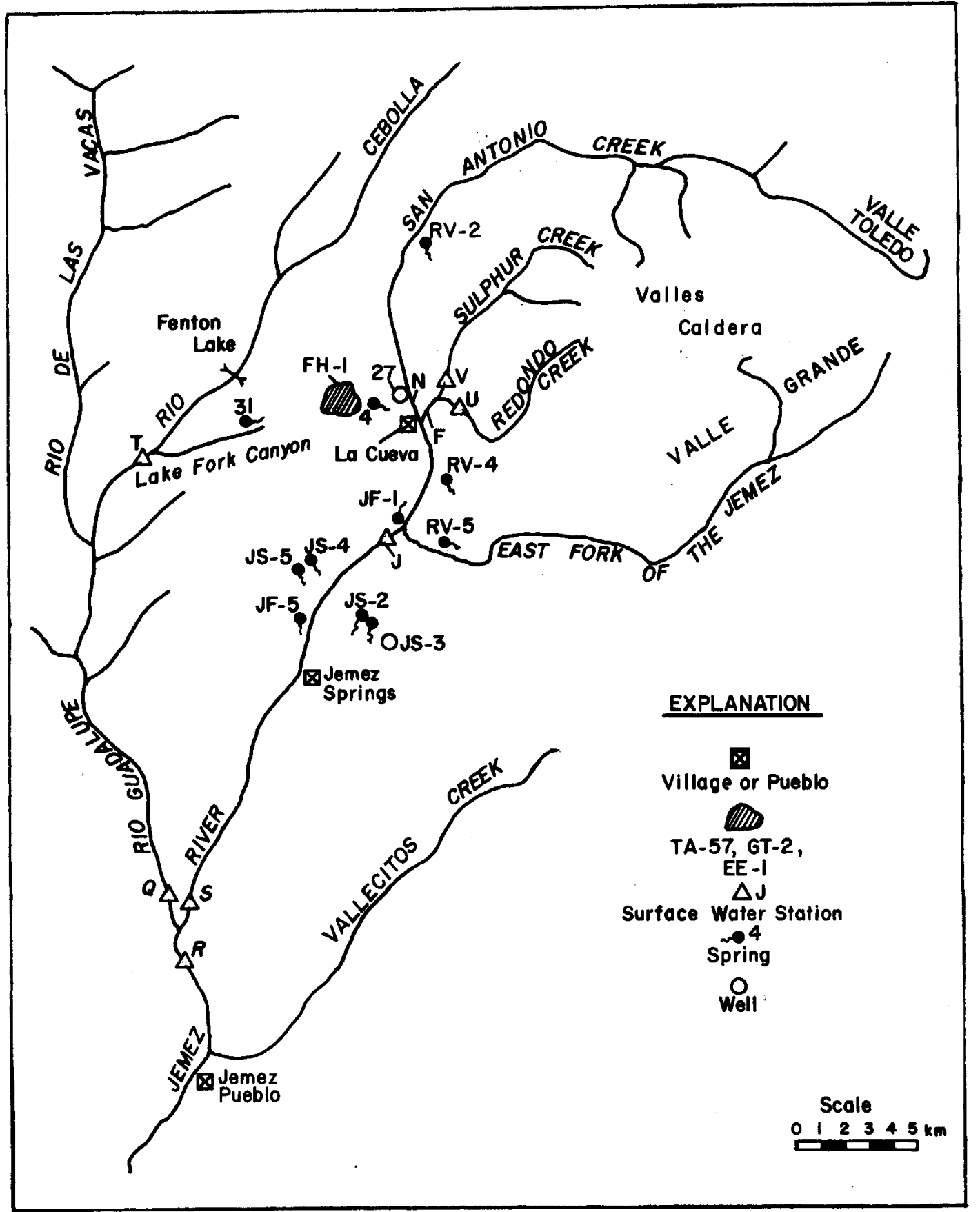

Fig. 8. Location of sampling stations.

$\begin{array}{ll}\text { F } & \text { Sulphur Creek } \\ \text { J } & \text { Jemez River } \\ \text { N } & \text { San Antonio Creek } \\ \text { Q } & \text { Rio Guadalupe } \\ \text { R } & \text { Jemez River } \\ \text { S } & \text { Jemez River } \\ \text { T } & \text { Rio Cebolla } \\ \text { U } & \text { Redondo Creek } \\ \text { V } & \text { Sulphur Creek } \\ \text { JS-2,-3 } & \text { Jemez Springs water supply }\end{array}$

$\begin{array}{ll}\text { JS-4, }-5 & \text { Jemez water supply } \\ 4 & \text { La Cueva water supply } \\ \text { JF-1 } & \text { Limestone Spring } \\ \text { JF-5 } & \text { Soda Dam } \\ 27 & \text { Hofheins Flowing Well } \\ 31 & \text { Cold Spring } \\ \text { RV-2 } & \text { San Antonio Hot Spring } \\ \text { RV-4 } & \text { Spence Spring } \\ \text { RV-5 } & \text { McCauley Spring } \\ \text { FH-1 } & \text { Fenton Hill water supply }\end{array}$




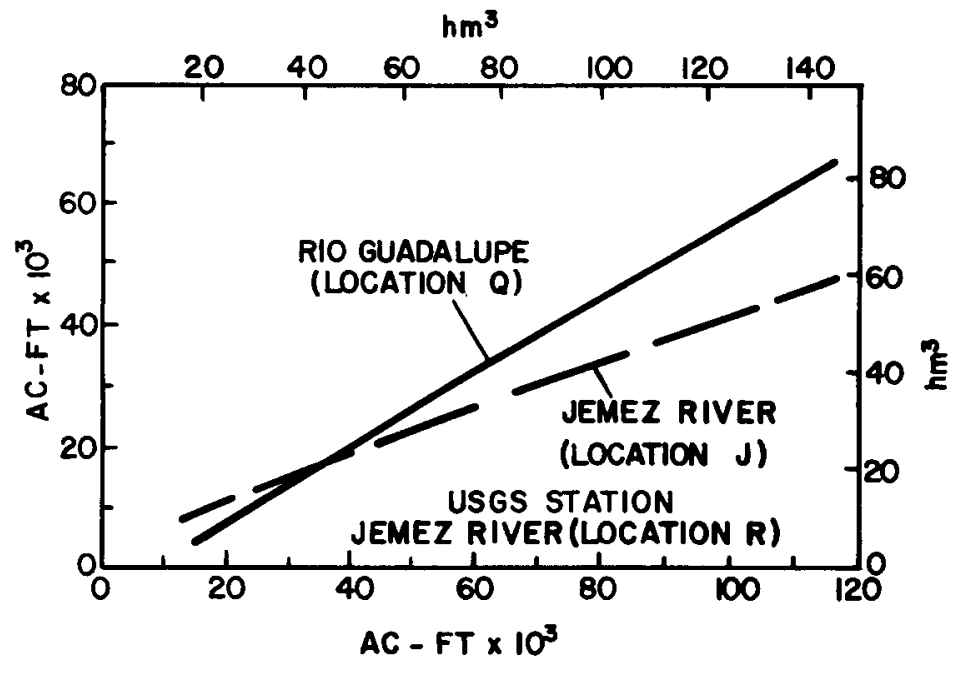

Fig. 9. Hydrograph to estimate volume of flow near Locations $J$ and $Q$ from US Geological Survey records from gaging station near Location $\mathrm{R}$. a standard water-stage recorder. Thus the day, hour, and peak discharges can be determined.

The discharge at the three stations ranged from 0.09 $\mathrm{m}^{3} / \mathrm{s}$ to $64 \mathrm{~m}^{3} / \mathrm{s}$ during the period 1960-75. The ratings are accurate to $\pm 10 \%$; thus, with the variable discharge, any small increase or decrease in flow would be impossible to determine. The USGS concurred that no additional useful data could be obtained by continued operation of the stations near Locations $J$ and $Q$, and the stations were abandoned in June 1976.

Several elements in the reservoir rock are known to be relatively soluble and therefore transportable to the surface in the heat-transfer water. They are arsenic, cadmium, fluoride, boron, and lithium. These elements can cause adverse environmental effects if the concentrations are sufficiently high in any waters leaving the site. However, these materials and any others found that are thought to cause adverse effects will be removed or concentrations sufficiently reduced from effluent waters pursuant to NPDES permit requirements.

b. Ground water. Several zones of subsurface water exist at the Fenton Hill Site below the $137-\mathrm{m}(450 \mathrm{ft})$ zone from which the presently permitted water is produced. An interpretation of the drill cutting sample from GT-2, located within $152 \mathrm{~m}(500 \mathrm{ft})$ of the location for the proposed water well, shows four sandstone zones perhaps containing water in suitable quantities. These zones are described in descending order. 18,19 
Abo formation

305-320 m (1000-1050 ft): $15.2 \mathrm{~m}$ (50 ft) of coarse, subround to angular, loosely consolidated sand of a beach or channel type. Geophysical log data interpretation indicates 18-20\% porosity and relatively fresh water. This zone should contain about $12330 \mathrm{~m}^{3}$ (10 ac-ft) per acre drained. Assuming 16-hectare (40-acre) drainage area and $30 \%$ recovery factor, production of $273000 \mathrm{~m}^{3}$ (60 Mgal) is feasible.

Madera formation

$440-450 \mathrm{~m}(1440-1480 \mathrm{ft}): 12.2 \mathrm{~m}(40 \mathrm{ft})$ of well consolidated tight, fine-ground calcareous sandstone. Geophysical log data interpretation indicates this zone to be tight and impermeable.

460-470 m (1520-1540 ft): $6.1 \mathrm{~m}(20 \mathrm{ft})$ of large grained to pebbly, subrounded calcareous sandstone. Geophysical $l o g$ data interpretation of a zone between $475-485 \mathrm{~m}(1560-1590 \mathrm{ft})$ indicates $13-17 \%$ porosity with $34 \%$ porosity in the interval of $475-479 \mathrm{~m}(1560-1570 \mathrm{ft})$. The water appears to be brackish and is estimated to be $5200 \mathrm{ppm}$ salt equivalent.

$540-550 \mathrm{~m}(1770-1800 \mathrm{ft}): 9.1 \mathrm{~m}$ (30 ft) of arkosic sandstone or granite wash. Geophysical $\log$ data interpretation indicates this zone to be only fair.

584-733 m (1916-2404 ft): lost circulation zone thought to be predominantly cavernous to fractured limestone with some light gray, gummy clay.

Top of Granite

$733 \mathrm{~m}(2404 \mathrm{ft})$.

Although each of these four zones are thought to contain water, they are untested. The two zones felt to be the most promising are the sandstones in the Abo at $305 \mathrm{~m} \mathrm{(1000} \mathrm{ft)} \mathrm{and} \mathrm{the} \mathrm{Madera} \mathrm{at} 540 \mathrm{~m}$ (1770 ft), although the lost circulation zone between 584-733 m (1916-2404 ft) cannot be overlooked. The shallower Abo sand would, of course, be preferable because of reduced costs for drilling and pumping, if a sufficient quantity of water is found.

In descending order, the first aquifer encountered is in the volcanics that overlie the Abo Formation. This volcanic aquifer is perched on the Abo 
that acts as an aquatard to any downward percolation. The volcanics were deposited on a well developed erosional surface cut into the Abo. It has been noted that some of the springs discharging from the volcanics do so at the outcrop of these ancient drainage channels in the Abo. This suggests that the Abo drainage system controls the principal flow of ground water in the overlying volcanics. The general absence of springs along the outcrop of volcanics implies that the saturated zone in the volcanics does not extend much above the top of the drainage channels. This is substantiated somewhat by Testholes $A$ and $B$, both of which are dry in the volcanic section of the holes. The water-supply well at Fenton Hill apparently encountered an artesian zone in the volcanics. This is based on the fact that water rose $3 \mathrm{~m}$ $(10 \mathrm{ft}$ ) in the well when the aquifer was penetrated. The specific capacity of the well of $6.4 \mathrm{l} / \mathrm{s}$ (100 $\mathrm{gpm}$ ) per $0.3 \mathrm{~m}$ ( $1 \mathrm{ft}$ ) of drawdown indicates a higher permeability than that found at the outcrop. This permeability coupled with a propinquity to potential discharge boundaries would also seem to argue that the Fenton Hill aquifer is confined or it would be quickly drained. Very few springs or wells produce from the Abo.

Underlying the Abo formation at a depth of $375 \mathrm{~m}$ (1230 ft) is the Magdalena group of shales and limestones. The geophysical logs suggest several possible aquifers in this group. The main water table was encountered at a depth of $533 \mathrm{~m}$ (1750 ft) in the Madera formation. All of the aquifers mentioned above this are perched. It appears that even the nearby San Antonio Creek is perched. The main aquifer occurs in a limestone that has cavernous type permeability. The temperature of the water implies that this formation is connected to and possibly draining the thermal water system in the caldera. This formation has some spring discharge to the Jemez creek in the reach from about Battleship Rock to Jemez Springs.

The volcanic aquifer is readily available and because it is confined would not appear to have direct effect on other users' supply. However, the areal extent of the aquifer is not known. It is likely that an aquifer in the Abo would also be confined and disconnected from a general system because many of the sandstones found in the Abo are lenticular in nature. The Madera formation west of the caldera collapse zone is an aquifer with a high permeability and large quantities of water. Withdrawal of $123300 \mathrm{~m}^{3} / \mathrm{yr}$ (100 ac-ft/yr) of water at Fenton Hill from such an aquifer would probably 


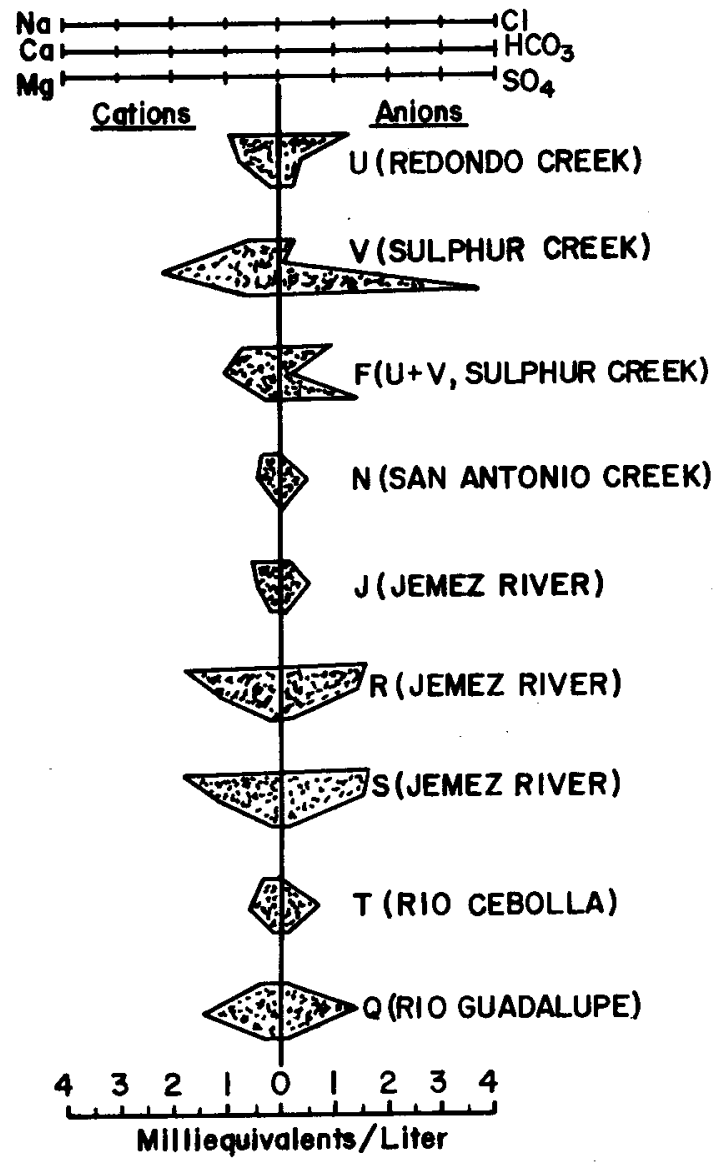

Fig. 10. Chemical analysis comparison of surface water, December 1974 . have little or no effect on any discharge to the surface water system because this quantity of water would have no practical effect on the altitude of the Madera water level. The few points of Madera spring discharge are usually obvious because Madera water contains hydrogen sulfide $\left(\mathrm{H}_{2} \mathrm{~S}\right)$ and has a high content of dissolved solids. Because of the poor quality, little beneficial downstream use is made of the Madera water. Figures 10-12 are chemical analysis comparisons of surface water, ground water, and thermal and mineral springs.

To protect the aquifers from potential contamination, the wellbores are cased as shown in Figs. 13-15. GT-2 was drilled with a 17-1/2-in. bit with 13-3/8-in. casing

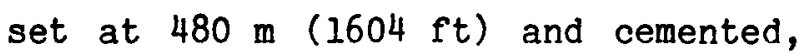

then the hole was redrilled with a 12-1/2-in.bit and 10-3/4-in. casing set at $773 \mathrm{~m}(2535 \mathrm{ft}$ ) and cemented to the surface as shown in Fig. 13. The fresh water zones are thereby double cased to $480 \mathrm{~m}(1600 \mathrm{ft})$, and the section below $480 \mathrm{~m}(1600 \mathrm{ft})$ is single cased.

EE-1 was drilled to a depth of $741 \mathrm{~m}$ (2431 ft) using a 17-1/2-in.-diam. drill bit and 13-3/8-in. casing set and then redrilled using a 12-1/2-in.-diam. bit and a 10-3/4-in. casing set and cemented, as shown in Fig. 14. The entire section through the top of the granite is double cased to the surface and cemented, thereby protecting the aquifers from any potential contamination that may result from the operation of the system.

Figure 15 is a schematic of the planned drilling and casing program for hole EE-2, at least through the section above the top of the granite. Noteworthy is the double casing through the section containing the water-bearing zones that protects these aquifers from possible contamination as a 


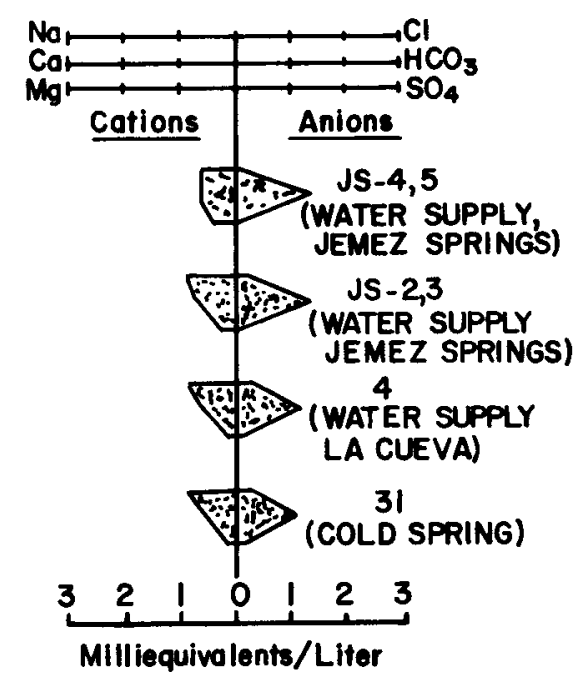

Fig. 11. Chemical analysis comparison of ground water discharges from Cenozoic-Volcanic overlying the Abo formation.

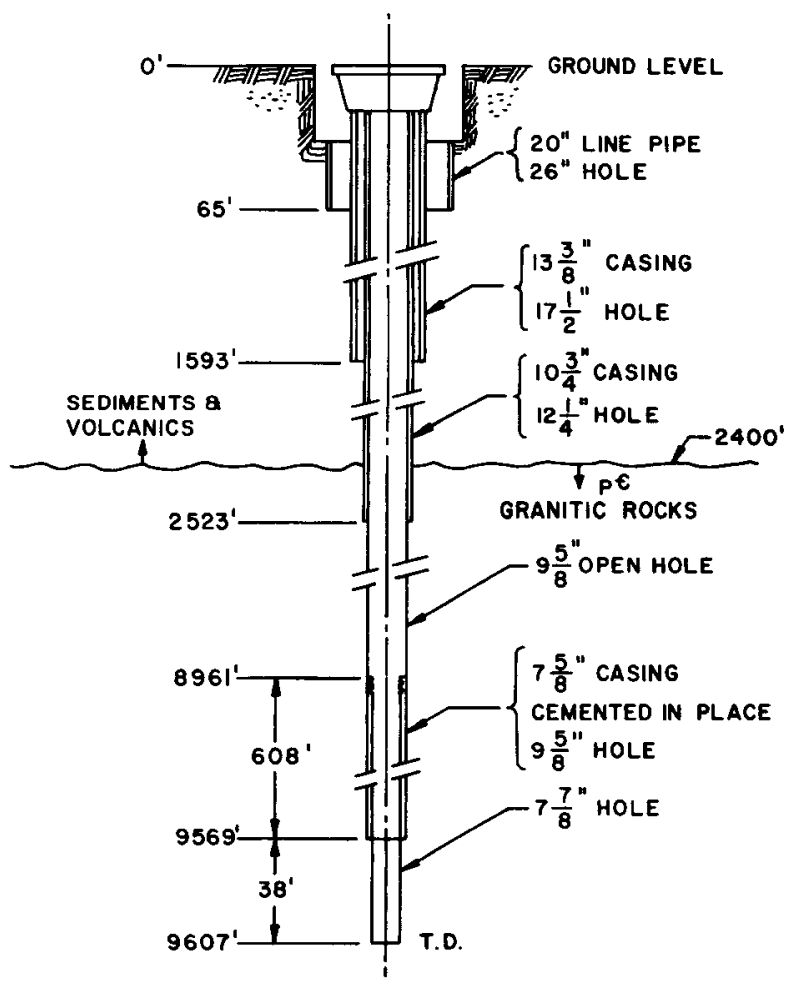

Fig. 13. Schematic of casing diagram of GT-2.

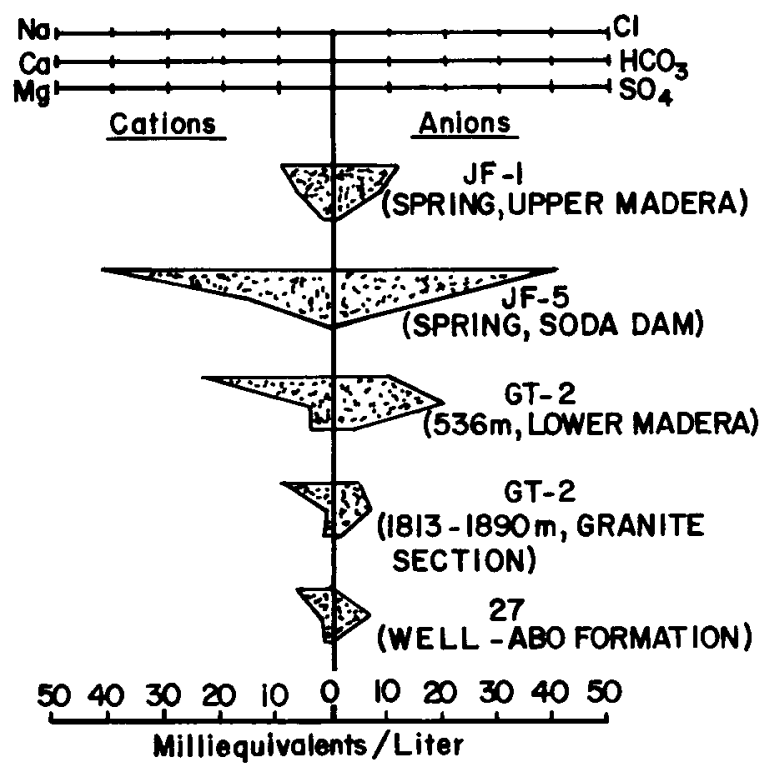

Fig. 12. Chemical analysis comparison from thermal and mineral springs.

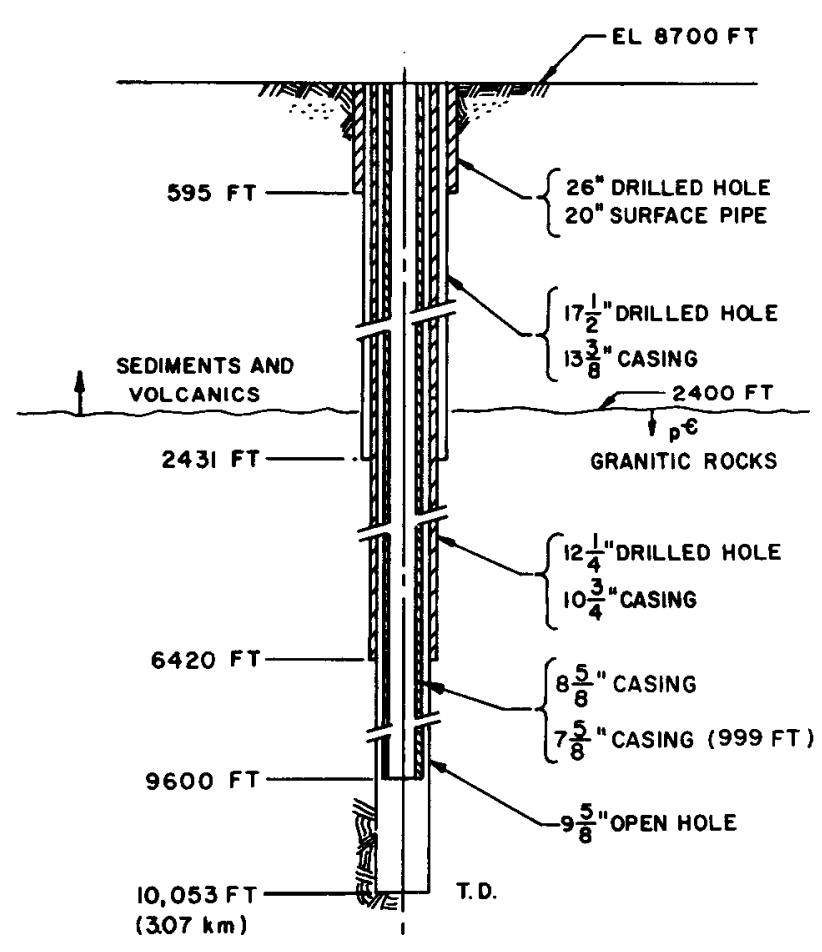

Fig. 14. Schematic casing diagram of $\mathrm{EE}-1$. 


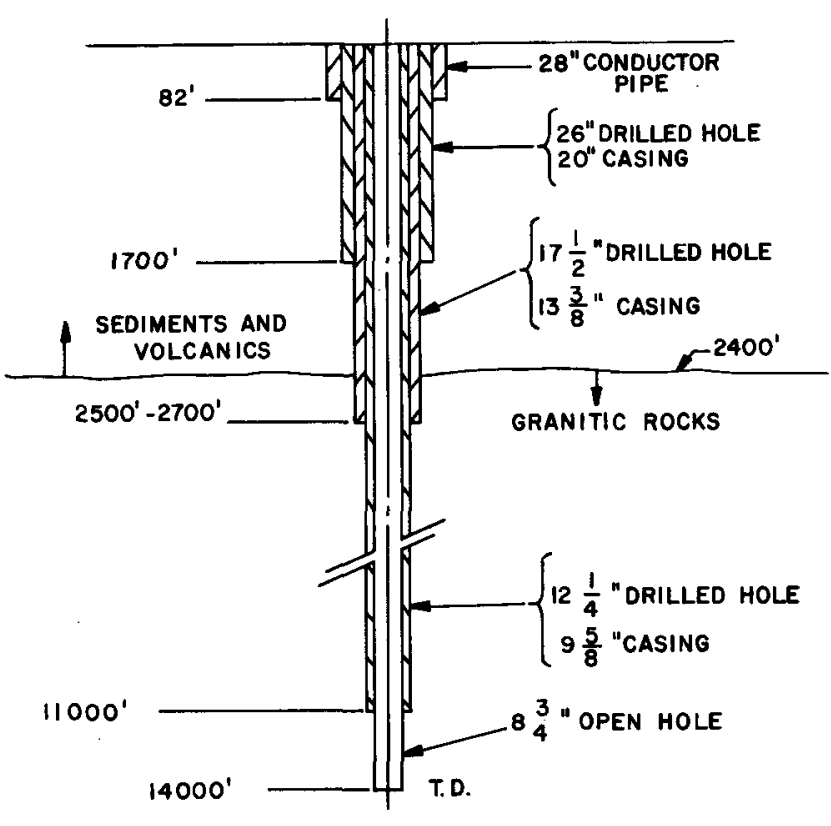

Fig. 15. Schematic casing diagram of proposed EE-2.

result of the the proposed system operation.

To advise and solicit comments, the New Mexico Environmental Improvement Division (EID), Water Quality Section's personnel were conducted on a tour of the Fenton Hill Site and briefed on the potential for water quality problems relative to site operation. Although no written comments have been received, verbal indications have been received, and the EID perceives no conflict with New Mexico Ground Water Regulations.

5. Climatology. The Jemez Mountain range is typical of most southwestern mountains in its general weather patterns. The climate is characterized by localized convective shower activity during the summer and more regional major storms during the winter. Total precipitation received generally increases at higher elevations; however, the irregular terrain causes irregularities in the storm patterns.

Temperatures of the region are generally mild, with few days exceeding $32^{\circ} \mathrm{C}$ in the summer and few nights dropping below $-18^{\circ} \mathrm{C}$ in the winter. Nevertheless extreme diurnal fluctuations in temperature can occur. For example, in the spring, daytime temperatures may rise to $20^{\circ} \mathrm{C}$ and nighttime temperatures may drop below freezing $\left(0^{\circ} \mathrm{C}\right)$.

Although some generalizations about the weather patterns can be made, specific events in these mountains tend to be localized. The localization makes it impossible to extrapolate weather events from one area to another. Because of the lack of climatological information at or near the site a few basic weather parameters were measured to determine the climatic regime of the area and to characterize prevailing wind patterns. These data will be used to determine where potential environmental contaminants released from the site 


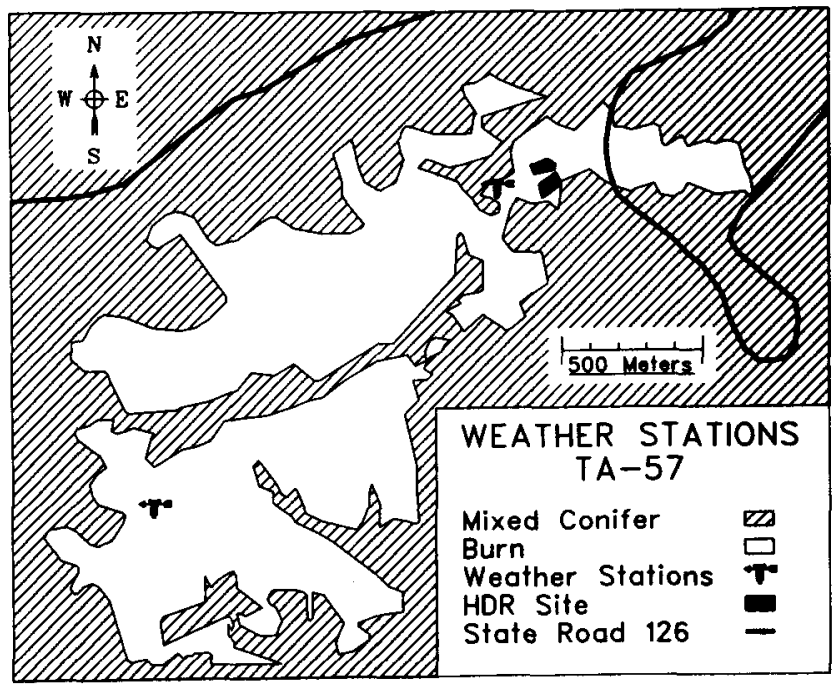

Fig. 16. Location of the weather stations near the site. will go and to explain variations in biological measurements that may be linked directly to climatological phenomena.

A weather station was established in $1975 \sim 150 \mathrm{~m}$ west of the site (LASL Technical Area 57 is TA-57). Its location, shown on Fig. 16, is as close to the site as possible to minimize the effects of surrounding terrain and structures upon air flow patterns. The station consists of a Meteorology Research Incorporated (MRI) mechanical weather station and $a$

weighing bucket rain gauge. The MRI mechanical weather station is mounted on top of a collapsible 9-m tower and records wind run, wind direction, and temperature on a pressure sensitive strip chart. The weighing bucket rain gauge, located $\Omega 10 \mathrm{~m}$ west of the tower, records precipitation on a strip chart attached to a revolving drum.

Another weighing bucket rain gauge is located on the Plateau $\sim 1500 \mathrm{~m}$ west of the site. This gauge, on the periphery of the area set aside for ecological studies, will be used to compare precipitation between the two locations. Some localized convection showers dump large quantities of moisture in nonuniform patterns in this mountainous terrain.

The weather station at the site has been recording data continuously since it became operational in Jaunary 1976. The data recorded by these instruments are reduced into hourly averages and put into a form that can be read by a computer. Then they are manipulated into monthly summaries in both graphical and tabular forms. Although no conclusions can be made about weather patterns from such a small data base, several interesting, but expected, phenomena are evident.

Air flow patterns have a distinct seasonal shift. During January the air flow is primarily from the northwest. Air flow patterns shift as the seasons progress into summer; an almost complete reversal is seen during August. 
Figures 7 and 8 of Ref. 3 show the normal seasonal sequence of continental air flow patterns.

Precipitation at the site also followed the pattern expected for semiarid southwestern mountain ranges. During the winter months, precipitation was a more or less random event and did not follow a predictable pattern. Table IV gives 1976 summaries by month for temperature, precipitation, and wind power. These data show that it was fairly dry at the site in 1976--only $35.66 \mathrm{~cm}$ of precipitation were recorded. Temperatures at the site were relatively mild with the extremes being between $-23^{\circ}$ and $27^{\circ} \mathrm{C}$ for winter and summer, respectively.

6. Aesthetics. A portion of the existing site can be seen from State Highway 126 by visitors to the area. Figure 17 is a photograph showing the site as it would appear to a passer-by. The tower in the foreground is the superstructure over hole EE-l that is $12.2 \mathrm{~m}(40 \mathrm{ft}) \mathrm{high}$. The facility has

TABLE IV

TEMPERATURE, PRECIPITATION, AND WIND SUMMARIES FOR 1976

\begin{tabular}{|c|c|c|c|c|c|}
\hline & \multicolumn{3}{|c|}{$\begin{array}{c}\text { Temperature } \\
\left({ }^{\circ} \mathrm{C}\right)\end{array}$} & \multirow{2}{*}{$\begin{array}{c}\begin{array}{c}\text { Precipitation } \\
\text { (mm) }\end{array} \\
\text { Total } \\
\end{array}$} & \multirow[t]{2}{*}{$\begin{array}{c}\text { Wind Power } \\
\text { Average } \\
\left(\mathbf{W} / \mathbf{m}^{2}\right)\end{array}$} \\
\hline & Av & $\operatorname{Max}$ & Min & & \\
\hline January & -6 & 9 & -23 & 4.8 & 15.9 \\
\hline February & -3 & 9 & -17 & 41.4 & 24.7 \\
\hline March & -3 & 10 & -17 & 17.5 & 38.4 \\
\hline April & 2 & 13 & -13 & 21.1 & 26.9 \\
\hline May & 7 & 19 & -6 & 45.0 & 16.8 \\
\hline June & 14 & 27 & 2 & 6.1 & 20.9 \\
\hline July & 14 & 26 & 5 & 74.9 & 7.9 \\
\hline August & 13 & 24 & 5 & 69.1 & 7.9 \\
\hline September & 10 & 22 & -1 & 45.7 & 7.4 \\
\hline October & 3 & 18 & -8 & 4.8 & 13.9 \\
\hline November & -1 & 13 & -23 & 17.5 & 10.8 \\
\hline December & -4 & 9 & -14 & 8.6 & 9.6 \\
\hline Total & & & & 356.6 & 201.1 \\
\hline Average & 3.8 & 16.6 & -9.2 & 29.7 & 16.8 \\
\hline
\end{tabular}


the appearance of a small industrial development and may be considered as aesthetically unpleasant in this mountainous forest setting, even though evidence of the 1971 Cebolleta fire still persists and has also marred the natural beauty of the area.

The facility is within a travel-influence zone, and as such, access by casual passers-by will be limited by the perimeter fence. Further, to make the site more aesthetically pleasing, a three member LASL Site Aesthetics and Cleanliness Suggestions Committee has been appointed. Among the actions already taken from the recommendations of this committee were to:

- install a perimeter chain-link fence with a main gate and a 76.2-m (250-ft) length of black vinyl on either side of the gate;

- plant 50 trees between the highway and the site;

- repaint the towers and all surface facilities in earthtone colors;

- remove all excess materials and scrap; and,

- contact the Youth Conservation Corps and arrange the planting of 5000 trees in the vicinity.

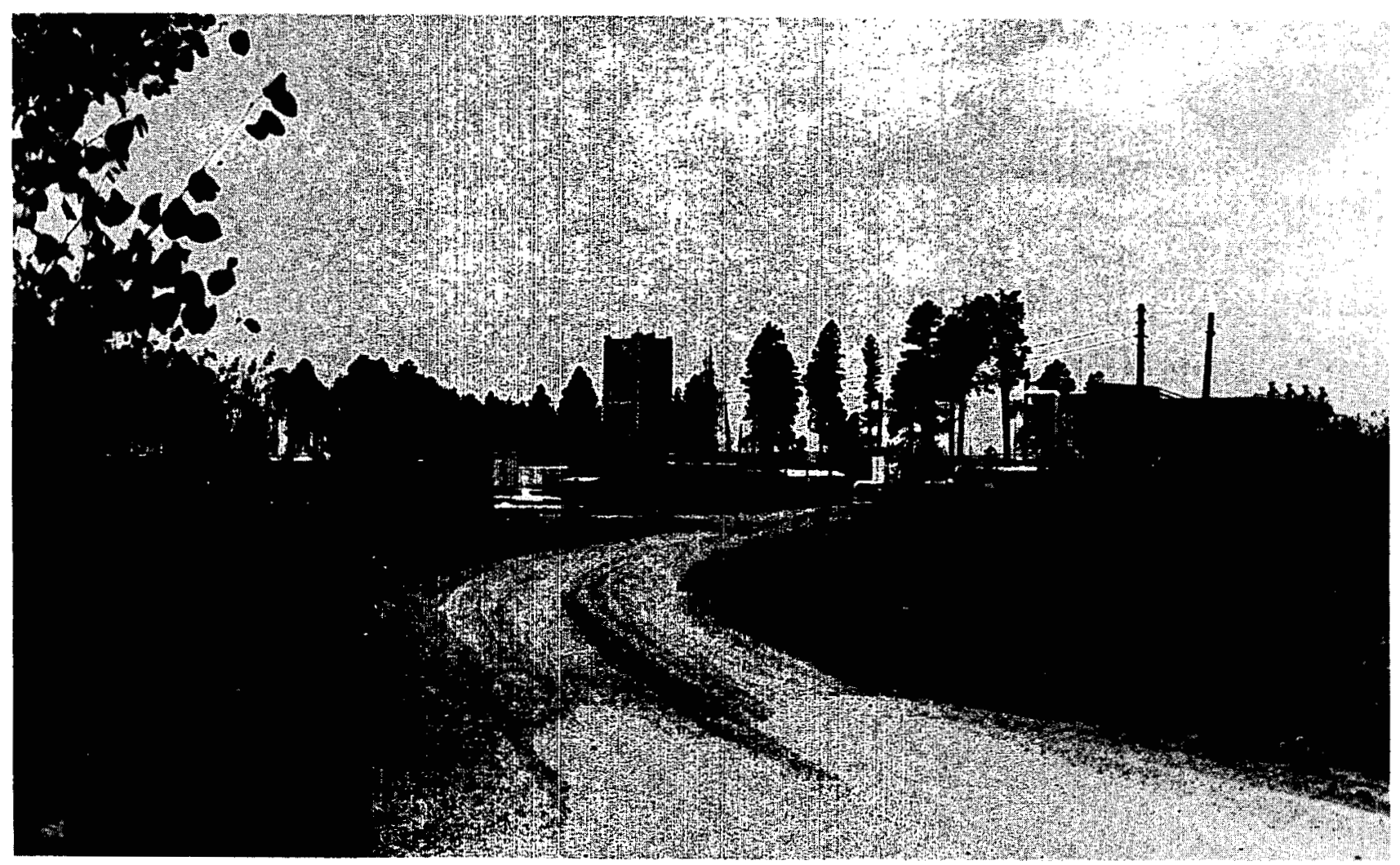

Fig. 17. View of Fenton H1ll Site from Highway 126. 
Additionally, the new electric power distribution lines within the site are to be buried.

\section{Biological Factors ${ }^{3}$}

During 1976 studies were initiated to measure various characteristics of birds, small mammals, elk, and vegetation at the site. These studies established base line data from which we can compare future measurements.

1. Vegetation. Three major vegetative complexes or community types are found at the site. Typical climax vegetation found at $2600-\mathrm{m}$ elevation in northern New Mexico is a mixed coniferous forest or broad ecotone between upper elevation spruce-fir communities and lower elevation ponderosa pine communities. A wildfire in 1971 destroyed parts of this climax vegetation at the site, resulting in the formation of two additional community types. The fire scar was aerially seeded with a mixture of higher elevational pasture grasses and legumes shortly after the fire. One year later, ponderosa pine tree seedlings were planted 3 to $5 \mathrm{~m}$ apart. The resultant secondary succession has developed into a grass-forb community interspersed with small stands of aspen suckers.

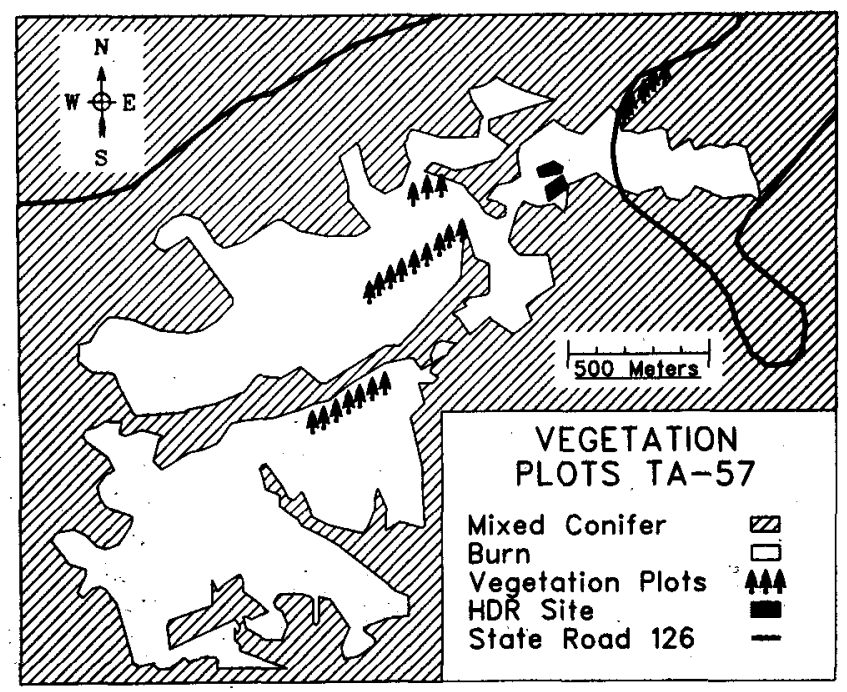

Fig. 18. Location of vegetation transects.
Transects placed in each community type to measure cover and density of the species were read in the spring, summer, and fall during the 1976 field season. The locations of these transects, 5 in the mixed coniferous forest, 3 in the new growth aspen, and 16 in the grass-forb community, are shown in Fig. 18. Taxonomic voucher specimens were collected and are on file at LASL.

After summarizing the 1976 plant population field data by community type, 15 dominant species were selected from which to characterize all community types. Only 
those species that contributed at least $0.1 \%$ cover in any community type were selected. The cut-off point of $0.1 \%$ cover eliminated those species that did not contribute significantly to the total vegetative biomass, yet it left enough species so that a good cross section of the dominants was found within all community types. As expected, the mixed coniferous community is dominated by tree species with a rich understory of shrubs. Douglas fir and white fir species (Pseudotsuga menziesii and Abies concolon, respectively) make up about three-fourths of the areal tree cover within this community type, with the rest being predominantly ponderosa pine. Aspen has cover values equivalent to several of the understory shrubs.

Unlike the other two communities, the aspen community is dominated by aspen (Populus tremuloides). However, there is an understory of shrubs and grass that represents species from both the mixed coniferous and grass-forb communities.

The mixed coniferous community has $\$ 50 \%$ more areal cover than the other communities. This represents almost four times the areal cover found in the grass-forb community and about one-third more areal cover than is found in the aspen community.

The same types of differences seen in vegetation parameters between the various communities are seen within the nonliving ground cover. Table $V$ gives the average ground cover by category for each community. The grass-forb

TABLE V

AVERAGE PERCENTAGE OF GROUND COVER BY COMMUNITY TYPE

\begin{tabular}{|c|c|c|c|}
\hline & Grass Forb & Mixed Conifer & Aspen \\
\hline Bare & $38.0 \pm 8.4^{\natural}$ & $4.9 \pm 5.4$ & $12.6 \pm 10.2$ \\
\hline Grass & $29.5 \pm 10.1$ & $1.5 \pm 1.4$ & $4.9 \pm 0.4$ \\
\hline Stick & $14.2 \pm 6.1$ & $18.9 \pm 7.8$ & $20.9 \pm 12.5$ \\
\hline Gravel & $10.2 \pm 4.6$ & $0.3 \pm 0.8$ & $0.2 \pm 0.9$ \\
\hline Bark & $2.9 \pm 2.5$ & $4.2 \pm 3.0$ & $13.6 \pm 21.5$ \\
\hline Leaf & $3.7 \pm 1.6$ & $23.4 \pm 23.4$ & $47.4 \pm 21.3$ \\
\hline Cobble & $1.2 \pm 1.1$ & $2.3 \pm 3.7$ & $0.2 \pm 0.4$ \\
\hline Feces & $0.3 \pm 0.6$ & $0 \pm 0$ & $0.2 \pm 0.9$ \\
\hline Rock & $0 \pm 0$ & $0 \pm 0$ & $0 \pm 0$ \\
\hline Needle & $0 \pm 0$ & $41.0 \pm 22.6$ & $0 \pm 0$ \\
\hline Cone & $0 \pm 0$ & $2.6 \pm 4.4$ & $0 \pm 0$ \\
\hline
\end{tabular}


community is dominated by dead grass, the mixed coniferous community has a ground cover dominated by needles, and the aspen community is dominated by leaves. The amount of exposed bare ground is greatest under the grass-forb community and smallest within the mixed coniferous community.

2. Small Mammals. The primary consumers or herbivores are one of the more abundant forms of wildlife in any ecosystem. Because small mammals feed on a large cross section of plant material, they are easily affected by toxic elements released into the environment. Data from studies made to determine small mammal populations surrounding the HDR Site represent a base line for one of the potential bio-indicators of environmental impacts from the LASL HDR Project.

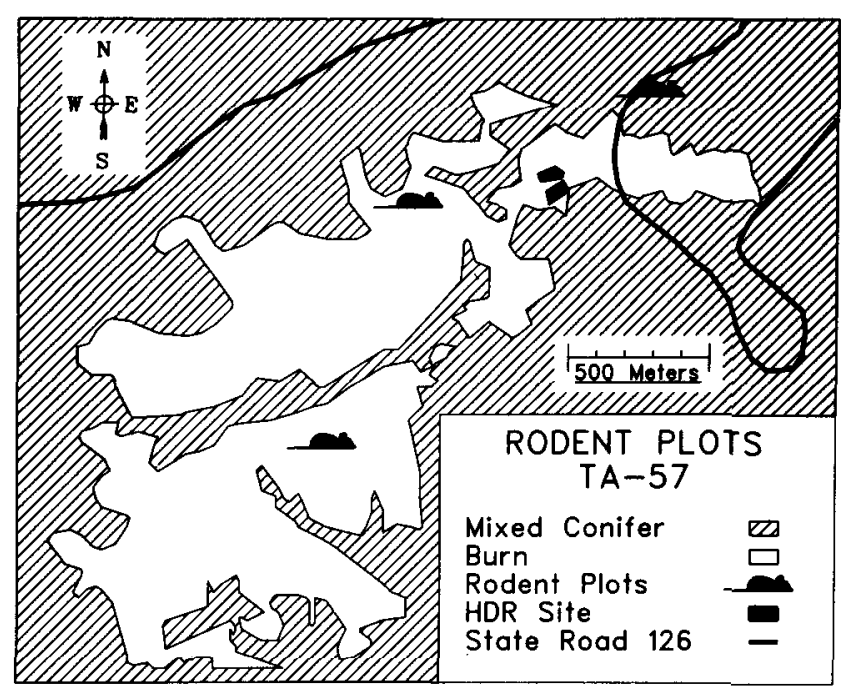

Fig. 19. Location of small mammal traplines.

Small mammals were live-trapped within each community to determine the trap susceptibility of the various species and their relative abundance among the communities. One trapline per community was established as shown on Fig. 19 and checked simultaneously during each trapping session.

Two trapping sessions were held during the 1976 field season. The first session was held in midsummer before the rodent population reached maximum numbers. The second trapping session was held in late summer-early fall to measure peak populations. Data from the two sessions were compared to determine whether the time of trapping has any affect on the interpretation of results.

Each trapping session consisted of two nights of prebaiting to familiarize the rodents with the traps, followed by three consecutive nights of trapping. Traps baited with a mixture of rolled oats and peanut butter were set up in the late afternoon and examined the following morning. This schedule prevented animals from being trapped during the hot part of the day and drastically reduced the chances of mortality as a result of heat exhaustion. 
A large square of cotton in each trap gave the rodent something to burrow into, and this reduced the death rate from excessive trauma.

The rodents were classified by species, sex, and age. They were weighed, then marked by a standard toe amputation technique. Dead specimens were tagged, frozen, and stored. These specimens will be used to compare elemental body burdens with specimens caught in the future if we encounter significant changes in rodent populations or if releases should occur at the HDR Site.

In addition to trapping by community type, traps were set up in six areas (three downwind and three down the principal drainage from the site) to establish a data base from which to compare future trapping results. These comparisons will be used to determine if a gradient is established within these rodent populations as a result of the LASL HDR Project and if this project is adversely affecting the local environs.

Within the three vegetative complexes mentioned earlier, the species trapped most often is the deer mouse (Peromyscus maniculatus). The data collected show that the grass-forb community contains the highest numbers of small mammals, yet it has the lowest species diversity.

These relationships were expected because the more closed community types offer more habitats and shelters for small mammals. However, most of the small mammals trapped were primarily herbivores, and the grass-forb community has more vegetative biomass within reach of the small mammals. Therefore, the high numbers of small mammals encountered in the grass-forb community could be a result of an abundant food supply, whereas the greater species diversity found in the more closed communities could be an indication of the more diverse forms of shelter.

The high percentage of trappings indicates that these vegetative communities support substantial populations of small mammals. This was also expected because small mammal populations tend to reach high levels in areas that have been disturbed.

3. Elk. With establishment of the grass-forb community on this Plateau, following the wildfire in 1971, this area has become an important winter range for the Rocky Mountain elk (Cervus Canadensis). Elk, one of the major big-game species of New Mexico, tend to be disturbed by human activity. Therefore, establishment of the HDR Site on the edge of this burn may eventually result in elk leaving this area. 


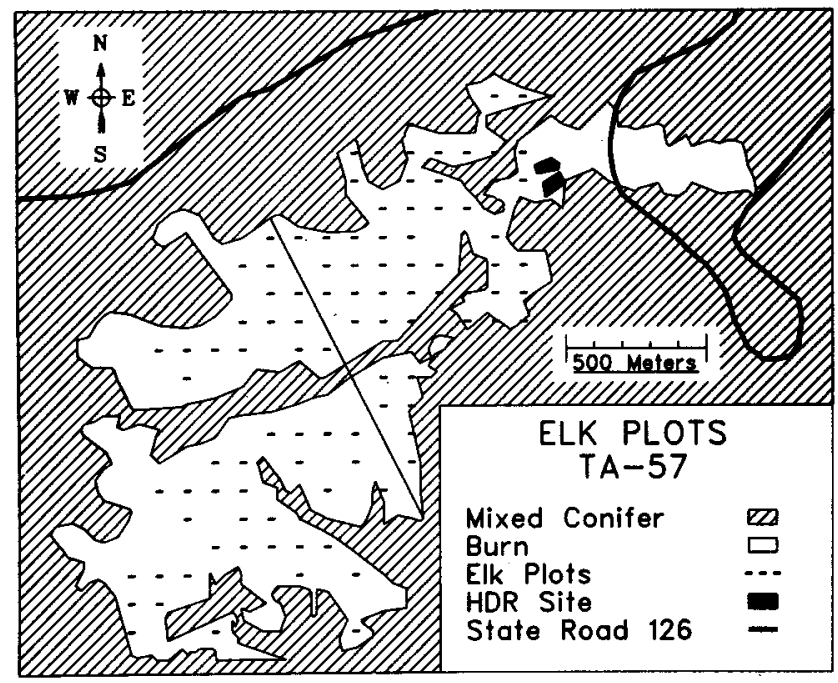

Fig. 20. Location of elk pellet group counting plots.

A stratified random set of permanently marked counting plots for pellet groups (fecal material) was established and read during mid-1976 to document elk usage of this burn area and to create a data base from which to compare future measurements.

The burned area was arbitrarily divided. Approximately $50 \%$ of the plots were adjacent to and $50 \%$ of the plots were away from the site as shown on Fig. 20. Each pellet group counting plot was $4 \mathrm{~m}$ wide by $22 \mathrm{~m}$ long. Plots were examined by two persons who physically removed all pellet groups from the plots and checked each other's work. It was therefore assumed that few, if any, pellet groups were overlooked. Physically removing the pellet groups, rather than marking them, ensures that future examinations will be made on new pellet groups and that the data collected are related to elk usage of the area after establishment of the Fenton Hill facility.

The pellet group counting plots cannot be fully interpreted from the initial set of readings. However, statistical tests between the two areas are nonsignificant, indicating that elk usage within the grass-forb community has been distributed uniformly in the past.

4. Birds. The avian community is perhaps the most mobile faction of wildlife found in any ecosystem. Typically, the avian component will change constantly throughout the year because of the seasonal emigration and immigration of the various species.

Two extensive plots were established on the plateau, one adjacent to and one away from the site, to describe the avian community dynamics and to quantify the impacts on these populations from the facility, as shown on Fig. 21.

The study plot adjacent to the site (the well site) is $250 \mathrm{~m}$ wide by $500 \mathrm{~m}$ long. This plot falls mostly within the mixed coniferous community. Parts of this plot have been encroached upon by expansion of the site. The 


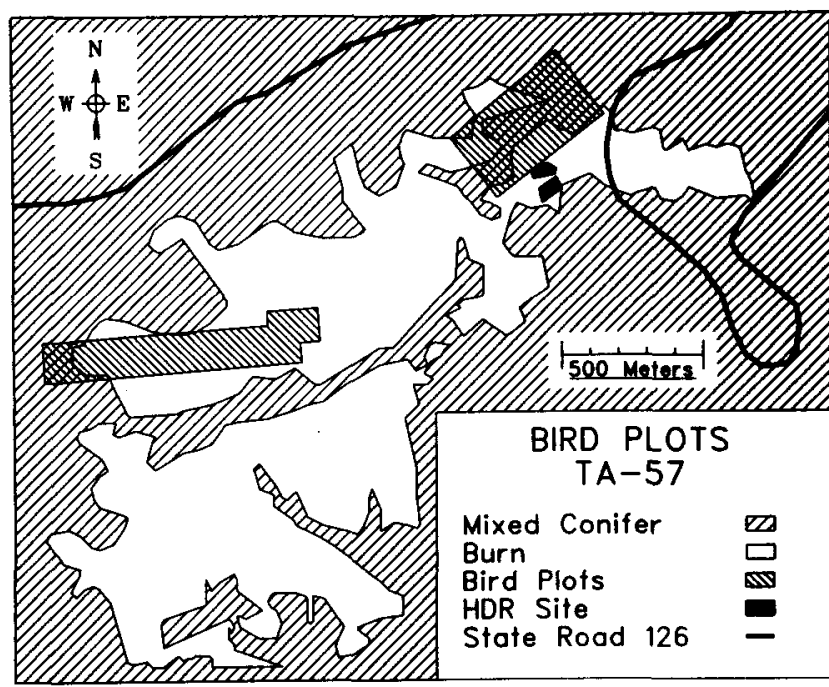

Fig. 21. Location of bird counting transects. study plot, which is $\Omega 1000 \mathrm{~m}$ west of the site, is $5150 \mathrm{~m}$ wide by $1000 \mathrm{~m}$ long and predominantly falls within the grass-forb community.

Both plots were examined seasonally during 1976 by personnel who walked specific lines through the plots at $50-\mathrm{m}$ intervals. The number and species of birds were recorded, together with personal observations about their suspected activities. These data were reduced into nesting pairs by species per unit area, densities of resident and transient species, and an overall categorization of the avian component of this ecosystem.

of the many transient bird species recorded during the census period, 41 species were identified. The high elevation and cold weather, however, prevented most birds from nesting and becoming residents.

Table VI gives the estimated nesting populations from data collected from both study plots. The greater number of nesting pairs recorded at the well site can be explained by the community type that dominates the area. The plot adjacent to the site falls within a predominantly mixed coniferous community, whereas the plot away from the site falls within a grass-forb community. The mixed coniferous community should allow more nesting sites and subsequently more nesting pairs of birds.

5. Endangered Species. Several animals on the Endangered Species List have been sited in the general area. The Jemez Mountain salamander is relatively widespread in the vicinity of Valle Grande, and its range may extend westward to the Fenton Hill Site. However, this salamander is thought to be generally confined to the canyons rather than the mesas.

Sightings of peregrine falcon have been noted in the vicinity of the site, but no nesting areas have been found. Page 36 of the Geothermal Leasing Final Environmental Impact Statement states that several other unique and endangered 


\section{TABLE VI}

ESTIMATED NESTING POPULATIONS AT THE WELL SITE

AND OPEN MESA SITE DURING THE SUMMER OF 1976

(Pairs Per 40.5 hectare)

\begin{tabular}{l}
\multicolumn{1}{c}{ Species } \\
\hline Black-chinned hummingbird \\
Common flicker \\
Yellow-bellied sapsucker \\
Hairy woodpecker \\
Traillis flycatcher \\
Western wood pewee \\
Violet-green swallow \\
White-breasted nuthatch \\
Pygmy nuthatch \\
House wren \\
American robin \\
Western bluebird \\
Warbling vireo \\
Yellow-rumped warbler \\
Western tanager \\
Cassin's finch \\
Green-tailed towhee \\
Gray-headed junco
\end{tabular}

Total

\section{Well Site Open Mesa Site}

4

7

4

2

$-\cdot$

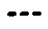

$-\cdot-$

$-\cdot$

$\cdots$

2

-..

2

$-\cdot$

$\cdots$

$\cdots$

$\cdots$

11

4

36

species may inhabit the area and include Rio Grande cutthroat trout, the southern bald eagle, the osprey, and the black-footed ferret. Several of the species listed in Table VII have only historical records of occurrence in the region and, in fact, have long been absent. None of them are known to breed in or inhabit the immediate vicinity of Fenton Hill because the area is a nearly flat mesa with no surface water.

\section{Social and Economic Factors}

Two villages in the vicinity of the site are La Cueva and Jemez Springs. La Cueva is located $2.4 \mathrm{~km}(1.5 \mathrm{mi})$ south of the site and has a permanent population of $\$ 50$ persons. Jemez Springs, located $13 \mathrm{~km}(8 \mathrm{mi})$ south of the site, has a population of $\$ 500$. Prior to the development at Fenton Hill and the Union 0il/Public Service Company (Baca Location) geothermal site, the area was visited by tourists. Although the villages of La Cueva and Jemez Springs were previously undergoing a slow growth, a mild acceleration of that growth 
has been experienced as a result of the geothermal developments presently under way. The population of La Cueva, in particular, periodically experiences temporary growth from trailer residences brought in by the drilling crews working at either Fenton Hill or Baca. To date these increases have not posed the "boom town" problems experienced at other much larger development areas. However, as a result of the small influx, both La Cueva and Jemez Springs have experienced a minor economic growth but will remain rural-type villages.

TABLE VII

ANIMAL SPECIES LISTED AS ENDANGERED BY THE STATE OF NEW MEXICO

\section{Species}

Mammals

Marten (Martes Americana origenes)

Black-footed ferret (Mustela nigripes)

Mink (M. vison energumenos)

Jaguar (Felis onca arizonensis)

Birds

Zone-tailed hawk (Buteo albonotatus)

Bald eagle (Haliaetus leucocephalus)

Osprey (Pandeion haliaetus carolinensis)

Peregrine falcon (Falco peregrinus anatum)

Whooping crane (Gnus americana)

Blue-throated hummingbird (Lampornis clemenciae)

Broad-billed hummingbird (Cynanthus latirostris)

Red-headed woodpecker (Melanerpus erythrocephalus

caurinus I

Baird's sparrow (Ammodramus bairdii)

Amphibia

Jemez Mountain salamander (Plethodon neomexicanus)

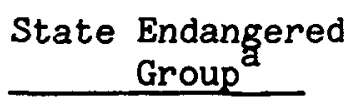

II

$I^{b}$

IIC

$I^{b}, c$

II

Ib

II

$I^{b}$

$I^{b}$

II

II

II

II

II

\footnotetext{
astate endangered group: I, species whose prospects of survival or recruitment in the state are in jeopardy; II, species whose prospects of survival in the state may become in jeopardy in the foreseeable future.

$b_{\text {Listed by the federal government as endangered. }}$

${ }^{c}$ Historical record only.

Source: J. P. Hubbard, M. C. Conway, H. Campbell, G. Schmitt, and M. D. Hatch, Handbook of Species Endangered in New Mexico, New Mexico Department of Game and Fish, 1978.
} 
Several Indian reservations exist in the region as shown in Fig. 22. These Pueblo. Indian populations are small and tend to maintain a remote interaction with outside populations and developments. One perceivable, although remote, impact to these reservations would be a reduced water resource as a result of the subsurface water produced at Fenton Hill. The hydrology of the area between the Fenton Hill Site and the several reservations is not well known. As pointed out earlier, the water zones of this area are lenticular and the water is thought to be perched, or confined, or both. Therefore, water withdrawal at Fenton Hill should not affect any water supply available to the reservations.

\section{EFFECTS OF IMPLEMENTATION}

Actions to be taken to minimize undesirable effects include dust control measures, reseeding of cut and fill areas, disposal of slash, placement of underground lines, and appropriate paint color selection.

\section{A. Land Status and Uses}

After completion of the drilling, redrilling, and construction of new facilities, the EE-2/EE-1 loop system will be operated for an extended fluidcirculation experiment. The system is designed to operate continuously for at least six months. For routine facility operation, there will be about 12 persons on the site during the daytime hours and 5 persons during night and weekend hours as operating and maintenance staff.

Should an excavated water-storage pond be used, additional land will be required. However, the pond could eventually provide water for wildlife and serve as a reservoir for USFS fire-fighting activities.

\section{B. Physical Factors}

1. Geography and Topography. Facilities, such as the portable experimental generating unit and the greenhouse structure, will be placed within the new fence and will not require new clearing or alteration of the topography. They will alter the appearance of the complex only slightly and should not result in any significant impact.

Soil disturbance will be minimized when placing underground water, power, and telephone lines by using a hose lay ripper. 


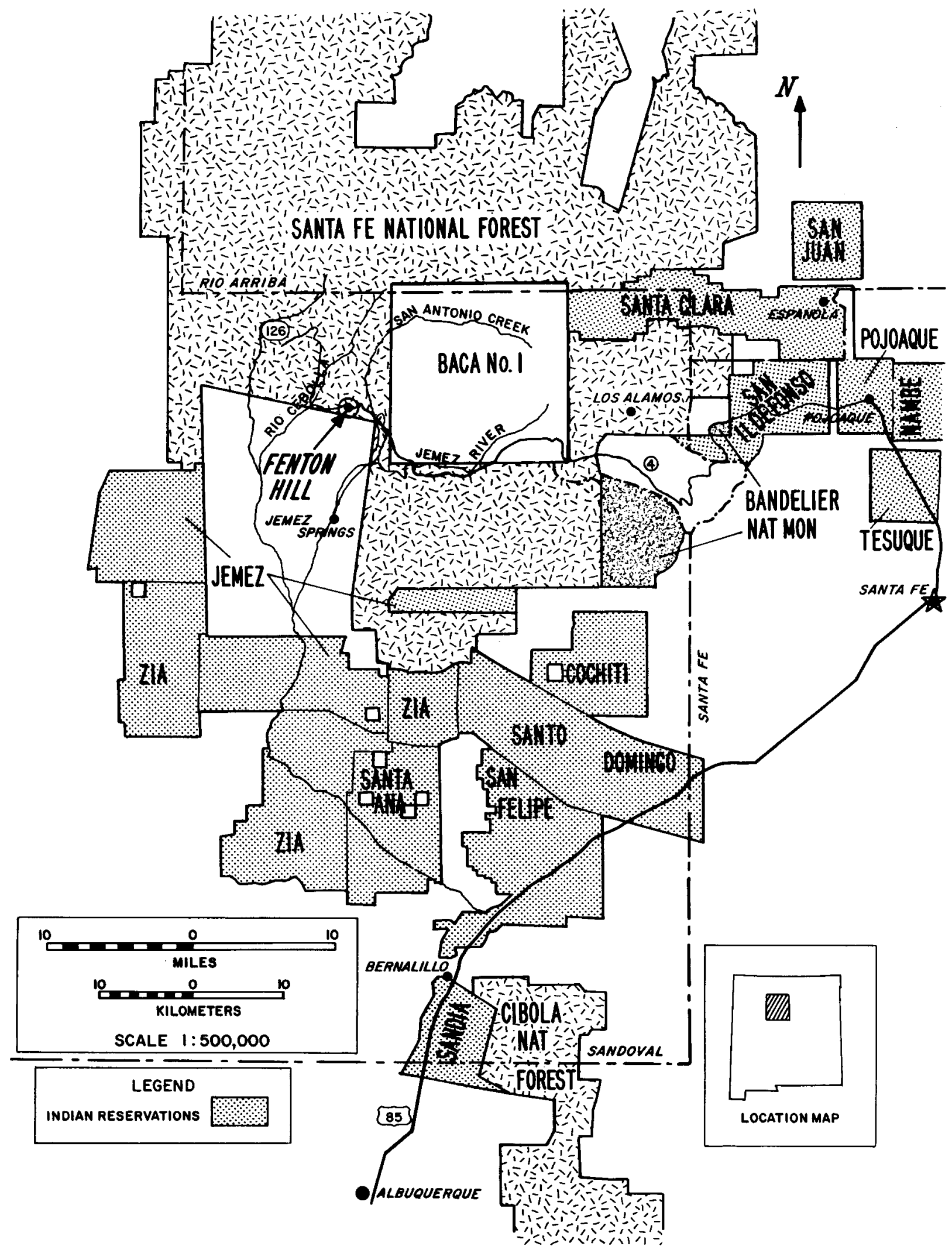

Fig. 22. Indian reservations in the vicinity of the Site. 
Approximately 5.5 hectares ( 13.5 acres) of land have been modified. This includes well pads, holding ponds, buildings, towers, movement of roads, etc. This disturbed land mass should now remain essentially constant, limited to the area within the boundary fence, except for the possible construction of the new water-storage facility and seismic monitoring stations.

Ground surface subsidence is not expected to occur. The fracture system will be created at great depth, $s 4 \mathrm{~km}(13000 \mathrm{ft})$. The fracture is expected to be pancake-shaped, with a radius of a few hundred meters, and vertically oriented. Even after several years of circulation, a porous zone is not expected to be more than about a meter (a few feet) thick. Thus, the overlying competent crystalline rock should provide adequate support. Furthermore, pressure will be maintained to at least a hydrostatic level in the zone during the entire experiment, and the fracture will be left filled at the conclusion. Ground levels and tilt are being monitored before, during, and after the experiments to fully document the actual situation. 13

2. Geology. No perceivable changes to the geology will occur except that a portion of the deep-seated granite will be artificially fractured and a small amount of the dissolved mineral content will be removed and transported to the surface. This dissolved material when separated at the surface will resemble the products of weathered granite and should not be objectionable. ${ }^{20}$

3. Seismology. Several of the most important factors controlling or indicating the possibility of earthquakes induced by fluid injection are: (1) the presence of known faults or large subsurface fractures; (2) high levels of ambient tectonic stress (sometimes indicated by pre-existing or ongoing seismic activity); and (3) a hydrologic regime dominated by subhydrostatic pressures below the water table. The combination of careful site selection with regard to both existing faults and natural earthquakes, controlled injection and operating pressures, and modest fluid volumes make it appear that the earthquake hazard associated with the proposed operations is extremely small. Nevertheless, the risk must be taken seriously.

a. Activities at the Fenton Hill Site. After EE-2 has been drilled to the desired depth, hydraulic fractures will be produced near the bottom of the wellbore by pressurization using fluid pumped into the wellbore. The array of 
seismic detection systems will be active during pressurization to record microseismic events that may result from the fracturing operation. During hydraulic fracturing experiments in 1975, a geophone package in the wellbore near the zone being fractured detected a number of acoustic emissions (much too small to be called microearthquakes), and their signal levels were so low that no signal was observed at surface seismic stations where the amplification is limited by the ambient (background) noise. Surface stations have located events $>15 \mathrm{~km}(9 \mathrm{mi})$ away whose magnitudes were as small as $M_{L}=-1.5$.

When hydraulically fracturing at greater depths and higher temperatures, we expect that the differential stresses will not be significantly greater than in the shallower existing fractured region; and therefore, there should be no change in the induced seismicity risk. Despite the low earthquake risk at the site, seismograms are closely monitored during the hydraulic fracturing experiments. Any observed local activity would be cause to reduce the flow pressure. If any seismic event occurs within a few kilometers of Fenton Hill that is either felt or the duration of humanly imperceptible ground motion exceeds 3-1/2 min, the pumping operations will be stopped and the wellbore pressure reduced immediately. Thereafter the system will be operated only when the source region is Identified, and there is no likelihood of triggering a damaging earthquake $\left(M_{L}>3\right)$. Based on water injection experiences at the Rocky Mountain Arsenal in Colorado, this action should avoid triggering an earthquake. 21 To establish a base line of natural seismic activity, measurements of the seismic background in the area are being made continuously.

b. Other Activities in the Area and Adjacent Regions. ${ }^{13}$ Confusion in observed selamic signals could occur between the activities at Fenton Hill and other manmade and natural causes in this area. As indicated above, the reglonal network has a locational accuracy of $\pm 5 \mathrm{~km}$ or better for events having magnitudes above $M_{L}=1 / 2$ to 1 over most of the area of the Jemez Mountains. Any significant source beyond $10 \mathrm{~km}$ from Fenton Hill can reasonably be assumed to be not connected with project activities. Three classes of man-caused sources need to be considered in this connnection: (1) mine blasting operations, (2) possible triggered earthquakes from the filling of Cochiti Reservoir on the Rio Grande, and (3) possible induced seismic signals from the Union $0 i 1$ Company's geothermal operations on the Baca Location property $\Omega 7-10 \mathrm{~km}$ east of the Fenton Hill Site. 
(1) Mine Blasting. The closest significant mining activity to Fenton Hill is the Earth Resources Company open pit copper workings at the mouth of Senorita Canyon (near Cuba, NM) about $23 \mathrm{~km}$ northwest of Fenton Hill. Ripplefired charges of $<454 \mathrm{~kg}(1000 \mathrm{lb})$ of ammonium nitrate usually occur at shift change times during working days and do not appear as noteworthy events on the regional network records. The mine has been either closed or only operated intermittently. The blasting location can easily be identified by the arrival times of the seismic waves at the Eureka Mesa station $<5 \mathrm{~km}$ northeast.

(2) Filling of Cochiti Reservoir. Cochiti Reservoir is $42 \mathrm{~km}$ southeast of Fenton Hill, and events at the two sites are easily separable by arrival time readings at regional network stations.

(3) Union Oil Geothermal Development Area. The Union 0il development program involves utilization of steam or hot water from wells along Redondo Creek on the Baca Location property. Not enough information is available concerning details of fluid injection or withdrawal to adequately evaluate whether triggered seismicity is a credible possibility. No significant seismic events have been observed at the seismic stations from this area. Because the Fenton Hill and Union Oil Co. sites are separated by only 7-10 km, it could be difficult to determine responsibility for events occurring approximately midway between the two. If a number of events were to occur, additional portable high-gain self-recording seismograph units may be deployed.

\section{Hydrology.}

a. Water Requirements. The quantity of water required for initial injection to saturate the pore field of the EE-2/EE-1 reservoir is 528000 to $55000 \mathrm{~m}^{3}$ (7-15 Mgal), and theoretical calculations indicate a total upper limit of as much as $150000 \mathrm{~m}^{3}$ (40 Mgal) through FY81. Makeup water will be needed thereafter to replenish losses into the rocks and to fill enlarging fractures. Once stabilized the makeup water rate is expected to be between 0.3 and $3.2 \mathrm{l} / \mathrm{s}$ ( 5 and $50 \mathrm{gpm}$ ). Pumpage from the existing well of $s 15000 \mathrm{~m}^{3}$ ( $\mathrm{s} 12 \mathrm{ac}-\mathrm{ft}$ ) in a 10-month period resulted in $\Omega 0.5 \mathrm{~m}$ ( $1.7 \mathrm{ft}$ ) of drawdown, indicating a very limited effect on the aquifer. The well is operated under a permit from the New Mexico State Engineer that allows pumping of $22000 \mathrm{~m}^{3}(18 \mathrm{ac}-\mathrm{ft})$ in 1978 and $18500 \mathrm{~m}^{3}$ (15 ac-ft) thereafter 
through 1986 with the provision that $80 \%$ of the water be returned to surface water or the ground water reservoir.

The following water requirements are estimates based on the experience gained at the present Fenton Hill Site and extrapolation of that experience to the larger reservoir. The amounts shown represent the maximum need within the limits considered reasonable but will be withdrawn from either subsurface aquifers or taken from surface supplies.

FY79 (drill 1 new 3960-m (13 000-ft) hole)

Drill EE-2:

Experiments:

Total

$$
\begin{aligned}
& r 18500 \mathrm{~m}^{3}(15 \mathrm{ac}-\mathrm{ft}) \\
& \frac{\Omega 3700 \mathrm{~m}^{3}(3 \mathrm{ac}-\mathrm{ft})}{\Omega 2000 \mathrm{~m}^{3}(18 \mathrm{ac}-\mathrm{ft})}
\end{aligned}
$$

FY80 (deepen 2 existing holes)

GT-2 Redrill:

s $3700 \mathrm{~m}^{3}(3 \mathrm{ac}-\mathrm{ft})$

EE-1 Redrill:

Total

$$
\frac{\sim 3700 \mathrm{~m}^{3}}{\sim 7400 \mathrm{~m}^{3}(3 \mathrm{ac}-\mathrm{ft})}
$$

FY81 (new system operation)

Fill System:

Refill System:

Makeup:

Total

Because of the experimental nature of this program, the exact water requirements cannot be predicted. Hydrogeological studies indicate that much larger physical supplies of water are available in the deeper limestone aquifer. Possible ways of assuring legal availability of needed water are being explored.

b. Liquid Effluents. Leakage of circulating fluid into the streams, or into the aquifer. or natural springs, is highly unlikely because the operating procedures require total surface impoundment of drilling fluids and blockage by the insertion of casing into the geothermal holes to isolate the waterbearing zones in the volcanic and sedimentary rocks. 
Effluents from the ponds have been released into a small canyon tributary to Lake Fork Canyon south of the site. The alluvium in the upper 595-m (1950-ft) length of the canyon ranges in thickness from 0.6 to $1.8 \mathrm{~m}$ (2 to $6 \mathrm{ft}$ ); whereas in the lower part of the canyon at the confluence with Lake Fork, the alluvium thickens to more than $12 \mathrm{~m}$ (40 ft). The effluents released to date have infiltrated the alluvium within $300 \mathrm{~m}$ ( $1000 \mathrm{ft}$ ) of the ponds. As they move downgradient in the alluvium, there are additional losses of water into the underlying tuff. Twelve holes were drilled through the alluvium into the top of the tuff in May 1978. Four of those holes, at distances of 20,60, 295 and $915 \mathrm{~m}(65,200,970$ and $3000 \mathrm{ft})$ from the ponds, encountered water and were cased for monitoring purposes. After a release of effluents in May, the fluorides (F) in four holes were $<1 \mathrm{mg} / l$ or near normal for naturally occurring water in the area (Table VIII). Chlorides (CI) were elevated above natural concentrations and were near those concentrations found in the ponds. The four holes were dry in late June and early September. After a release in late September, only the holes at 20 and $60 \mathrm{~m}$ (65 and $200 \mathrm{ft}$ ) from the pond contained water. Fluorides were near natural levels, chlorides were elevated.

Soluble fluoride from analyses of cuttings from the 12 holes indicated natural concentrations were reached within $150 \mathrm{~m}(490 \mathrm{ft})$ from the ponds. Water samples and analyses of cuttings from the alluvium indicate a rapid uptake and adsorption of fluoride onto the soil. The chloride serves as a good tracer of water movement and indicates the effluents have infiltrated the alluvium and underlying tuff to a distance of $295 \mathrm{~m}(970 \mathrm{ft}$ ) from the ponds.

The shallower ground water aquifer at the Fenton Hill Site lies at a depth of $113 \mathrm{~m}(370 \mathrm{ft})$ in a tuff, perched on a shale and siltstone unit. The movement of water in this aquifer is toward the southwest where it discharges above the confluence of Lake Fork Canyon and Rio Cebolla (Cold Spring). The $\mathrm{Cl}, \mathrm{F}$, and total dissolved solids (TDS) are monitored at FH-1 (supply well TA-57, depth $137 \mathrm{~m}$ ) and in Lake Fork Canyon at a Forest Service stock well (depth $64 \mathrm{~m}$ ), and at Cold Spring. The Cl, F, and TDS from these wells and spring have remained normal and show no effect from the pond effluents.

Surface water samples were collected downgrade from the ponds in Lake Fork Canyon and in the Rio Cebolla. The Cl, F, and TDS were naturally occurring and showed no effects from pond effluents.

The latest discharge from the site occurred on November 7, 1978. The analysis of samples taken from that discharge are shown in Table IX. The 
TABLE VIII

AVERAGE CHLORIDES, FLUORIDES AND TOTAL DISSOLVED SOLIDS (TDS)

OF EFFLUENTS (PONDS) AND WATER FROM SAMPLING STATIONS, 1978

\begin{tabular}{|c|c|c|c|c|}
\hline \multirow[b]{2}{*}{ Station } & \multirow{2}{*}{$\begin{array}{c}\text { No. of } \\
\text { Analyses } \\
\end{array}$} & \multicolumn{3}{|c|}{$\mathrm{mg} / \mathrm{l}$} \\
\hline & & $\underline{C 1}$ & $\underline{F}$ & $\underline{\mathrm{TDS}}$ \\
\hline GTP-1 (pond) & 7 & 144 & 3.7 & 776 \\
\hline GTP-2 (pond) & 6 & 745 & 5.0 & 2096 \\
\hline GTP-3 (pond) & 8 & 794 & 6.0 & 2128 \\
\hline Hole $20^{a}$ & 2 & 736 & 0.6 & 1674 \\
\hline Hole $60^{a}$ & 2 & 746 & 0.5 & 1776 \\
\hline Hole $295^{a}$ & 1 & 62 & 0.2 & 380 \\
\hline Hole $915^{a}$ & 1 & 4 & 0.3 & 160 \\
\hline FH-1 (we11) & 5 & 7 & 0.3 & 274 \\
\hline USFS (we11) $2400^{a}$ & 1 & 3 & 0.5 & 106 \\
\hline USFS (tank) $6065^{a}$ & 4 & 3 & 0.2 & 68 \\
\hline Lake Fork $6065^{a}$ & 2 & 6 & 0.4 & 202 \\
\hline Lake Fork $7285^{a}$ & 1 & 7 & 0.3 & 254 \\
\hline Lake Fork $8500^{a}$ & 3 & 4 & 0.8 & 143 \\
\hline Lake Fork $9420^{\mathrm{a}}$ & 4 & 7 & 0.8 & 169 \\
\hline Cold Spring $9110^{a}$ & 4 & 4 & 0.7 & 146 \\
\hline Rio Cebolla $10330^{\mathrm{a}}$ & 3 & 8 & 0.5 & 134 \\
\hline
\end{tabular}

${ }^{a}$ Distance in $m$ downgradient from pond GTP-3

analyses were performed using an EPA approved technique and quantities are expressed in $\mathrm{mg} / l$, except $\mathrm{pH}$.

The heated water brought to the surface is reinjected after cooling by passage through the heat exchangers. At the termination of various phases of experimentation the circulation loop will be drained, and it will be necessary to release water from the ponds or tanks to the natural drainage course as has been done in the past. The water-storage capacity is sufficient for makeup water but not for total circulation-loop water.

The chemical quality of the water that would be discharged is expected to resemble past releases (Table $\mathrm{X}$ ). As water is circulated through the new 
CHEMICAL CHARACTERISTICS OF POND WATER, RANGES AND MAXIMA OBSERVED IN 1977-78

\begin{tabular}{|c|c|c|c|}
\hline Species & $\underline{m g} / \ell$ & Species & $\underline{\mathrm{mg} / \mathrm{l}}$ \\
\hline $\mathrm{SiO}_{2}$ & $85-300$ & Co & 0.01 \\
\hline $\mathrm{F}$ & $2-10$ & $\mathrm{Ni}$ & 0.03 \\
\hline As & 1 & $\mathrm{Cl}$ & $200-1100$ \\
\hline B & 9 & $\mathrm{Cu}$ & 0.05 \\
\hline $\mathrm{Cd}$ & $<0.1$ & $\mathrm{Zn}$ & $<0.2$ \\
\hline $\mathrm{Hg}$ & $<0.001$ & $\mathrm{Ag}$ & $<0.02$ \\
\hline $\mathrm{Li}$ & $3.8-10$ & $\mathrm{Sn}$ & $<0.1$ \\
\hline Mo & 0.04 & $\mathrm{Sb}$ & $<0.3$ \\
\hline $\mathrm{Se}$ & 0.004 & $\mathrm{Sr}$ & $<0.8$ \\
\hline $\mathrm{Be}$ & $<0.01$ & $\mathrm{Ba}$ & 0.2 \\
\hline $\mathrm{Na}$ & $150-500$ & $\mathrm{~Pb}$ & $<0.03$ \\
\hline $\mathrm{Mg}$ & 25 & $\mathrm{Bi}$ & $<0.1$ \\
\hline$A 1$ & 1 & $\mathrm{HCO}_{3}$ & $150-500$ \\
\hline $\mathrm{P}$ & 40 & $\mathrm{SO}_{4}$ & 190 \\
\hline $\mathrm{K}$ & 65 & $\mathrm{PO}_{4}$ & 0.9 \\
\hline $\mathrm{Ca}$ & 80 & TSS & 160 \\
\hline $\mathrm{V}$ & $<0.03$ & TDS & 2800 \\
\hline $\mathrm{Cr}$ & 0.003 & $\mathrm{H}_{2} \mathrm{~S}$ & $<0.1$ \\
\hline $\mathrm{Mn}$ & 0.2 & $\mathrm{pH}$ & $6-8 \mathrm{pH}$ units \\
\hline $\mathrm{Fe}$ & 6 & & \\
\hline
\end{tabular}

deeper fracture system at temperatures of $\$ 250-275^{\circ} \mathrm{C}\left(480-530^{\circ} \mathrm{F}\right)$, there will probably be more minerals dissolved, which may result in higher concentrations of some constituents. Those constituents will be regulated by an NPDES permit and will be removed as necessary by the water treatment facility. Thus the quality of the future discharges into the canyon is not expected to be significantly different from past discharges.

Some experiments will require the use of small amounts of chemical dye or radioactive tracers to study characteristics of subsurface flow. Both 
TABLE X

\section{LATEST DISCHARGE ANALYSIS RESULTS}

Analysis

pH

TDS

TSS

TS

$\mathrm{SiO}_{2}$

$\mathrm{Mg}$

$\mathrm{Na}$

$\mathrm{Fe}$

$\mathbf{K}$

Cl

$\mathrm{Ca}$

F

Al

$\mathrm{SO}_{4}$

$\mathrm{HCO}_{3}$

$\mathrm{CO}_{3}$

$\mathbf{P}$

B

As

Cd

Li
Pond Discharge

(mg/le)

8.3

1622.

$<1$.

1622.

168.

3.74

360 .

0.242

52.

600 .

66.

7.

0.270

111.2

300 .

$<1.0$

0.15

32.

0.300

0.001

8.3
15 m Downstreama

(mg/ll)

8.3

1597.

229.

1826.

140.

10.

288.

0.472

52.

550.

76.5

5.70

0.215

88.2

280.

$<1.0$

0.30

32.

0.273

0.001

6.55

a At this distance the total discharge had perculated into the ground.

techniques are common in oil field operations and have been adapted to the unique situation at Fenton Hill. Residuals of such tracers may be released into the ponds at times. The radioactive tracer most likely to be used is ${ }^{82} \mathrm{Br}$, which has a half-life of about $1 / 2$ day and thus decays to an undetectable level in 12 days ( 10 half-lives). No releases from the ponds will be made beyond the fence until the radioactive tracers have decayed to 
concentrations acceptable to the EPA for drinking water. The chemical dyes are not considered toxic unjess present in much higher concentrations than will be used for initial dilution in the circulating system.

Environmental monitoring and special environmental studies by LASL will continue in the vicinity of Fenton Hill to further understand the environmental effects, detect and document undesirable trends, and implement appropriate mitigating measures.

5. Climatology. An increase in thermal output from the heat exchangers could impact the microclimatology of the local environs. Depending on the size of the thermal plume and its trajectory, a portion of the larger coniferous vegetation might be damaged by desiccation in the winter. This would occur if the tops of the trees were forced into transpiration by warm air while the moisture on the ground remained frozen.

6. Aesthetics. Although the "industrial" appearance of the site cannot be totally obscured, the majority of the facility can be blended with the surrounding environment by the artful use of appropriately colored paint and screening. Those facility additions, which will necessarily be observable from the highway, will be painted colors that either blend or harmonize with the natural colors of the area. Should it become necessary, additional screening by planting trees can be used.

Should the excavated pond for water-storage be selected, it can be located either immediately northwest of the site or south of the proposed parking lot. The northwest location should not be observable from the highway. However, the location south of the parking lot will probably be observable and should be screened in some manner. The excavation of a storge pond at either location will require the handling of the soll removed. One technique would be to place the excavated material on the surrounding edge as a berm, thereby blocking view of the stored water or raising it above the eye level of passing motorists. Suitable planting will reduce the unnatural appearance of the berm. The security fencing that would be required to reduce liability would be appropriately painted or coated. The ponds are not expected to emit any unnatural odor beyond that of ordinary ponds.

During the period of drilling and redrilling an oil field drilling rig will be used. The mast will be readily observable because it is $\sim 39.6 \mathrm{~m}$ 
(130 ft) high. Color will not help the aesthetics of the mast because it would still be obvious because of its height. Drilling contract provisions will require that portable mud tanks be used instead of the more conventional excavated mud pit and will require site cleanliness during operation and cleanup following the drilling.

\section{Biological Factors}

1. Vegetation. Discharging of water into the drainage system next to the facility may have resulted in more vegetative growth in the stream channel; however, this has not been documented. If future plans for a tenfold increase in thermal output results in a concomitant increase in surface discharge, the dry canyon bottom might take on riparian characteristics with a consequent increase in diversity of the biota.

No signficant impacts have been observed that can be attributed to the facility other than the 5.5 hectares (13.5 acres) of vegetation that was disturbed.

2. Wildlife. Any disturbance to a natural environment will have some impact upon the wildlife; however, this change is not always detrimental. Studies currently being conducted ( 3 years of annual live trapping data and one year of bird flushing data) have shown the inftial fluctuations in small mammal and bird populations expected from these operations. These populations now appear stable. Unless an unforeseen future disturbance occurs causing a change in densities with a gradient away from the facility, this development will have had little environmental impact on these populations. It is premature to determine if the elk movement on the plateau is affected by the facility. Transects are being read that should supply new data. Comparisons between the data collected in 1978 and the initial readings of the 94 transects two years ago should be available soon. The pond water would not be suitable for livestock or wildlife because of elevated mineral levels. However, all discharged water will be treated before release and will be acceptable for animal use.

3. Endangered Species. The peregrine falcon has been sighted in the area, but as mentioned earlier, no known nesting areas are in the vicinity. 
Noise created during new hole drilling and more extensive system operation should not greatly reduce the falcon's hunting range.

The Jemez Mountain salamander is known to habit a large portion of the Jemez Mountains, and they may be attracted to an excavated water-storage pond. If so, some may inadvertently be killed during site operation.

\section{Environmental Contaminants}

1. Air. There is no gaseous effluent during steady (closed-1oop) operation or quiescent periods. When the system is vented to the ponds, some gases previously accumulated in the circulating pressurized liquid could be released to the atmosphere. A detailed analysis of gases from the present circulating system indicated that about $87 \%$ was air and about $13 \%$ was carbon dioxide $\left(\mathrm{CO}_{2}\right) .22$ As a crude comparison, the amount of $\mathrm{CO}_{2}$ potentially released from $3.8 \mathrm{~m}^{3}$ (1000 gal) of vented liquid is about the same as the $\mathrm{CO}_{2} \mathrm{ex}-$ hausted by a car driving $1.6 \mathrm{~km}$ ( $1 \mathrm{mi}$ ). Traces of hydrogen sulfide and ammonia were also measured but have not presented any odor problems at the site. These constituents were found in the circulating loop and have not been observed in the pond.

Radon ( $R n$ ) gas has frequently been raised as a potential environmental contaminant from geothermal operations. Radon, the radioactive gas produced by decay of naturally occurring radium, could accumulate in the circulating fluid from contact with granitic rock in the fracture system. The only time radon could be released to the atmosphere is when the system is vented and the liquid placed in surface storge. Measurements in the existing system have shown maximum concentrations of about $3 \mathrm{nCi} / \ell$ in the circulating-loop liquid after about 75 days of continuous operation. ${ }^{23}$ Theoretical interpretation indicated maximum levels of $s 11 \mathrm{nCi} / \mathrm{l}$ would be reached in about 160 days. If similar conditions prevail in the new, deeper fracture system, the estimated release of Rn during venting operations (assuming $\Omega 13 \mathrm{l} / \mathrm{s}$ or $200 \mathrm{gpm}$ ) would be No.01 Ci/day that could continue for $15-20$ days if as much as $\Omega 19000 \mathrm{~m}^{3}$ ( $5 \mathrm{Mgal}$ ) were vented. This amount of radon would be about the same as the radon released from natural soils covering an area of 25 hectares ( 62 acres) or less. 24 Thus, the effect would be small in comparison with natural background radioactivity. 
The rigs used to drill the new system holes will be driven by diesel engines and will emit gaseous and particulate exhaust products. Because this point source is small and drill rig engines are usually kept in good mechanical condition, little to no impact is expected.

2. Water. Soluble constituents of the deeper reservoir will be removed and will be contained in the circulating water. During loop operation these dissolved contaminants will be monitored to assure that concentrations do not reach levels that would harm either the reservoir, pumps, or pipes. Should the dissolved material approach such levels, the water will be treated to reduce the concentrations to acceptable levels. Circulating-loop water may occasionally be diverted to storage and as such will be confined to the site. Occasionally, the reservoir will be emptied requiring that circulating-loop water in excess of the storage capacity be discharged to the natural drainage from the site. This water is expected to exceed EPA standards, therefore it will be treated in the proposed water treatment plant, prior to discharge, pursuant to the NPDES permit currently under consideration.

3. Water Treatment Plant. The engineering design of this facility is still under consideration. However, without regard to the design, the water contaminating wastes removed will be disposed of by a subcontractor who will be legally required to dispose of the material from the site in a manner approved by the New Mexico Environmental Improvement Division. The waste material will not be disposed of on the site or on USFS lands.

Sanitary wastes will be discharged to the septic system at the trailer living area. This septic system will be designed in conformance with Public Health Service Publication No. 526, "Manual of Septic-Tank Practices" and New Mexico regulations governing liquid waste disposal. We are assuming that all sanitary liquid waste discharges will be into the soil tile fields and will not degrade the ground water.

4. Noise. The facility will cause some increased noise during operation and thus may degrade the aesthetic quality of the area. Noise levels were typically $<100 \mathrm{~dB}(\mathrm{~A})$, and pumping noise levels will generally be steady without major fluctuation. This should have little impact on the wildlife populations. These are much lower levels than those expected from the 
operation of the turbine-powered helicopter on the nearby USFS helipad.

Audio measurement devices will be used to record noise levels at various stations during the heat extraction experiment. Measurements at the fence surrounding the heat exchangers are usually $<70 \mathrm{~dB}(A)$. Thus, noise levels at the site should be no worse than a typical street corner.

A somewhat increased level of nolse, over that described above, will occur during drilling operations by the diesel engines used to power the drilling rig. This noise should not significantly impact the area's wildlife.

\section{E. Social and Economic Factors}

The proposed drilling, facility expansion, and longer operating periods will require additional labor and an increased number of on-site staff. The overall effect will be that an increased economic input to the local communities will be made beyond that of the past. Further it is expected that an increased expenditure in the area by USFS personnel will be made. Combined, this effect will continue to improve the economic well-being of the communities involved and the regional area in general. No social problems are expected, and no burden should occur to the existing infrastructure of the area.

\section{SUMMARY}

Now that the extraction of geothermal energy from hot dry rock has been successfully tested at Fenton Hill, another deeper, and therefore hotter, reservoir will be created. This system will be of a commercially feasible size to determine the "lifetime" or rate of thermal drawdown of the reservoir. The technique principally requires the use of existing technology with some modification of instruments and cables for operation at such high temperatures. A continuous 75-day test of the present circulation loop extracted $\backsim 5$ MW of thermal energy, and it is hoped that the larger reservoir will produce up to $50 \mathrm{MW}$ of energy. Because the concept and this use of the natural resource are unique, all phases of development, construction, and operation were monitored for any adverse effects. The environmental studies of the area were initiated before development of the site to establish a base line data set from which to evaluate any effects resulting from the project activities. The major concern was the possiblity of induced microearthquakes by fracturing the granitic basement rock and by the injection of such large volumes of pressurized 
fluid. Although none were detected, the on-site and regional seismic networks will continue to monitor the new system and may be expanded.

Studies of the surface and ground waters have indicated that the local hydrology should not be affected. Because the boreholes are cased with cement, there is minimal water loss through permeation into the reservoir rock. Dissolved rock constituents stabilized at near drinking water concentrations, and all water to be discharged from the site will be treated and should exceed EPA standards. Gases are released only when water is diverted to storage, and these were analyzed as $87 \%$ air and $13 \%$ carbon dioxide, with only trace levels of hydrogen sulfide and ammonia. Soluble radioactive elements decay to undetectable levels in a few days.

Besides heat exchangers, a possible demonstration generating plant, and a water treatment facility, the only other major surface facility is for water storage. This can be covered tanks, excavated holding ponds or earth-fill dams. There are no odor problems, and if the pond water was treated to reduce the level of minerals, it could be used by wildlife.

Energy from hot dry rock has thus far proved to be clean, as well as safe. Generating plants could be located within or near cities without concern of possible hazards or contamination. Also, a relatively small site is required, and the noise levels, except during drilling, are low. By screening with fencing and trees and by selection of appropriate paint colors, an HDR plant would not greatly affect the aesthetics of the area.

Another advantage of hot dry rock geothermal energy is that it does not represent a significant depletion of a natural resource. Therefore, it is an attractive alternative to resources, such as coal. If HDR-produced energy proves to be economically feasible, it will aid our pursuit of energy independence because hot dry rock is located at varying depths everywhere within the earth's crust.

\section{ACKNOWLEDGMENTS}

We would like to thank the following persons for their assistance in the preparation of this paper: K. Rea, E. Homuth, W. Purtymun, D. Cash, and J. Tubb. We also acknowledge the Department of Energy, Division of Geothermal Energy; the US Forest Service; and the Oak Ridge National Laboratory. 
REFERENCES

1. M. C. Smith, D. W. Brown, and R. A. Pettitt, "Los Alamos Dry Geothermal Source Demonstration Project," Los Alamos Scientific Laboratory Mini- Review 75-1 (May 1975).

2. A. G. Blair, J. W. Tester, and J. J. Mortensen, "LASL Hot Dry Rock Geothermal Project, July 1, 1975--June 30, 1976," Los Alamos Scientific Laboratory report LA-6525-PR (October 1976).

3. K. H. Rea, "Environmental Investigations Associated with the LASL Hot Dry Rock Geothermal Energy Development Project," Los Alamos Scientific Laboratory report LA-6972 (December 1977).

4. "Draft Environmental Statement for the Proposed Dry Geothermal Energy Source Demonstration," prepared by Los Alamos Scientific Laboratory for Jemez Ranger District, Santa Fe National Forest, Region 3 (October 1973).

5. W. D. Purtymun, "Geology of the Jemez Plateau West of Valles Caldera," Los Alamos Scientific Laboratory report LA-5124-MS (February 1973).

6. W. D. Purtymun, F. G. West, and R. A. Pettitt, "Geology of Geothermal Test Hole GT-2 Fenton Hill Site, July 1974," Los Alamos Scientific Laboratory report LA-5780-MS (November 1974).

7. F. G. West, "Hydrologic Summary of the Area of Fenton Hill Site TA-57," Los Alamos Scientific Laboratory, unpublished report (February 1979).

8. R. L. Smith, R. A. Bailey, and C. S. Ross, "Geologic Map of the Jemez Mountains, New Mexico," US Geol. Surv. Misc. Geol. Inv. Map I-571 (1970).

9. G. H. Woods, Jr. and S. A. Northrop, "Geology of the Nacimiento Mountains, San Pedro Mountains, and Adjacent Plateaus in Parts of Sandoval and Rio Arriba Counties, New Mexico," US Geol. Surv. Oil and Gas Inv. Prelim. Map 57 (1946).

10. C. A. Newton, D. J. Cash, K. H. Olsen, and E. F. Homuth, "LASL Seismic Programs in the Vicinity of Los Alamos, New Mexico," Los Alamos Scientific Laboratory report LA-6406-MS (November 1976).

11. W. D. Purtymun and H. S. Jordan, "Seismic Program of the Los Alamos Scientific Laboratory," Los Alamos Scientific Laboratory report LA-5386-MS (September 1973).

12. D. B. Slemmons, "Fault Activity and Seismicity Near the Los Alamos Scientific Laboratory Geothermal Test Site, Jemez Mountains, New Mexico, Los Alamos Scientific Laboratory report LA-59ll-MS (April 1975). 
13. R. A. Pettitt, nEnvironmental Monitoring for the Hot Dry Rock Geothermal Energy Development Project, Annual Report for the Period July 1975--June 1976," Los Alamos Scientific Laboratory report LA-6504-SR (September 1976).

14. W. D. Purtymun, F. G. West, and W. H. Adams, "Preliminary Study of the Quality of Water in the Drainage Area of the Jemez River and Rio Guadalupe," Los Alamos Scientific Laboratory report LA-5595-MS (April 1974).

15. W. D. Purtymun, W. H. Adams, and J. W. Owens, "Water Quality in Vicinity of Fenton Hill Site, 1974," Los Alamos Scientific Laboratory report LA-6093 (December 1975).

16. F. H. Rainwater and L. L. Thatcher, "Methods for Collection and Analyses of Water Samples," US Geol. Surv. Water-Supply Pap. 1454 (1960).

17. W. D. Purtymun, W. H. Adams, A. K. Stoker, and F. G. West, "Water Quality in Vicinity of Fenton Hill Site, 1975," Los Alamos Scientific Laboratory report LA-6511-MS (September 1976).

18. F. G. West, P. R. Kintzinger, and W. D. Purtymun, "Hydrologic Testing Geothermal Test Hole No. 2," Los Alamos Scientific Laboratory report LA-6017-MS (July 1975).

19. F. G. West, P. R. Kintzinger, and A. W. Laughlin, "Geophysical Logging in Los Alamos Scientific Laboratory Geothermal Test Hole No. 2," Los Alamos Scientific Laboratory report LA-6112-MS (November 1975).

20. J. Balagna, R. Charles, and R. Vidale, "Geothermal Chemistry Activities at LASL. January--December 1975," Los Alamos Scientific Laboratory report LA-6448-PR (October 1976).

21. J. H. Healy, W. W. Rubey, D. T. Griggs, and C. B. Raleigh, "The Denver Earthquakes," Science 161, 1301-1310 (1968).

22. K. H. Rea and V. Gutschick, "Environmental Assessment of Dissolved Gases in LASL's Hot Dry Rock Geothermal Source Demonstration Project," published in Geothermal Resources Council Trans. 2, p. 249-252 (July 1978).

23. P. Kruger, L. Semprin, G. Sederberg, and R. Potter, "Hot Dry Rock Energy Extraction Field Test," Los Alamos Scientific Laboratory progress report (in preparation).

24. M. H. Wilkening, W. E. Clements, and D. Stanley, "Radon 222 Flux in Widely Separated Regions," Natural Radiation Environment II, Symposium Proc., Houston, Texas, Aug. $7-11$, 1972, ERDA CONF-720805. 
